\title{
The Standard of Naval Strength
}

\author{
Lieutenant Carlyon Bellairs R.N. (Retd.), M.P.
}

To cite this article: Lieutenant Carlyon Bellairs R.N. (Retd.), M.P. (1907) The Standard of Naval Strength, Royal United Services Institution. Journal, 51:348, 123-183, DOI: 10.1080/03071840709431344

To link to this article: http://dx.doi.org/10.1080/03071840709431344

\section{曲 Published online: 11 Sep 2009.}

Submit your article to this journal

山ll Article views: 10

Q View related articles $\sqsubset$ 


\title{
THE STANDARD OF NAVAL STRENGIH.
}

\author{
By Lieutenant CARLYON BELLAIRS, R.T. (Retd.), AL.P.
}

Thursday, 6th December, 1906, at 3 p.m.

Admiral Sir R. H. Harris, K.C.B., K.C.M.G., in the Chair.

The Truditional Policy. "The Hlouse of Commons, eren when mast discontented and parsimonious, had always been bountiful, even to profusion, whero tho interests of the Navy wero concerned." Mlacaulay.

The l'arty I'icw is, "Navy above Party." "Large sacrifices had to be made, and it is satisfactory to know that in tho House of Common's there was not a hostile vote-and I think I'may almost say there was not a hostile speech-against tho proposals of Her Majesty's Government to strengthen tho Navy. And there is this remarkable fact, of which I think we all ought to be proud, that tho policy of increasing the Nary was talien out of the domain of party politics."-Earl Spencer (Liberal) at Mansion IIouse, 10th November, 1894.

"I venture, with very great respect, to remind the Houso that naval administration is not a party question; that it neret has been treated as such; and I sincerely hopo that past practico will bo followed in the present instance."-Mr. Pretyman (Conservative), 7th March, 1005.

MIY last paper on the standard of strength was read on 27th June, 1904, when the present Secretary of State for Foreign Affairs was in the Chair. It dealt largely in a condemnation of the expendituro of previous years. The danger now is that we appear to be swinging to the other extreme.

In 1904 I took the unusual course of quoting in an appendix selections from the sayings of statesmen, sailors, soldiers, historians, and economists about the maintenance of our sea power. Naval supremacy is the key to all efficiency and all economy, so we need not wonder why Adam Smith placed it bofore free trado itself I indulged the ambitious hope that my paper and those quotations would assist continuity of policy. In the paper the lato Lord Salisbury's words wore quoted: "The defence of the country is not the business of the War Office or the Government; but the business of the people themselves." - If this is the case, we certainly do nothing to educate our masters. The Return of Flcets (Great Britain and VOL. II. 
Foreign Countries), analysed in Appendix S, is about the only informa* tion handed to the public. The people lack the historic sense, and no adequate attempt is made, as is done in Germany, to cultivate it in the schools of the country. We seldom learn from history; we never look to the future. Consequently; warnings are neglected; we live in reactions from one extreme to another. And when the danger which was foreseen by a fcw is visible to all, we have a wasteful panic. I advocate the teaching of history as of paramount importance.

\section{Personfel.}

The 1904 paper did not deal with the personnel for the reason that the present permanent force is certainly up to, if not beyond, our requirements. We are able now to man all existing ships without touching the Royal Naval Reserve. The tendency of invention is towards fewer ships and smaller crews. Uniform armament of heavy. gums, turbines, and oil fucl all mean smaller crews, while the tendency is for the power of several ships to bo concentrated into one. It is very important to remember that the chief waste of naval war is the opposite to that of land war, in that it is a loss of matériel rather than of personnel. After a few wceks or months of war we are likely to have a redundancy of men.- This is most pronounced in the engineroom complements under the protective deck, more so than among the exposed executive and marine branches above. The rule is, that unless the ship sinks, there are no casualties below the protective deck. The great advantage derived therefrom is, that the fighting and navigating portious of the crew, on the one side, and the engine-room on the other, can specialise in their difficult and widely separated spheres of work.

The country that brings this spocialisation to its highest pitch of efficiency is the one that wili make the best use of its matéricl. Liko battles, the approaches to perfection are only to be won by a lifotimo's concentration, and int by dispersion of effort. One word more with reference to this subject. No system of training the personnel is likely to be successful which does not carry with it, if not the enthusiastie support of the $\mathrm{Nivy}$, at Ieast the support of the great majority of the officers of .that Service. I have now stated the conditions of the problem, and on those conditions we must judge the relative merits of the German system and the one we are about to introduce afloat from Dartmouth, and from the ships for training stokers as mechanics and watchkeepers. How, then, are we to get the best intelligent opinion of the Service on this as on all other matters? It is only by full and impartial inquiries, by untrammelled discussions in this Institution, or by the three P's-Press, Parliament, and Platform. A wise administration of the Admiralty should endeavour to bring these things to pass with a view to facilitating its own work.

\section{Distribution of Ships.}

To secure efficiency, not only is concentration required inside the unit ship, but there must be a concentration of units themselves in large fleets in such a manner as to reproduce as nearly as possible the conditions of war. Sea training in association with large fleets of the most modern vessels is the ideal; and it is from this point of view that any redistribution scheme must be judged. . A country 
which has no second line of defences must necessarily keep her only defence in a state of greater preparedness than the sea forces of nations who are well able to defend themselves on shore. $\Lambda$ t the same time, no nation should be pressed to keep the whole Navy in peace on a war footing.

The difficultics of the Government next February, when they carry out their redistribution scheme, will be of their own seeking. They elected to state in a memorandum that an increase of efficiency results from reducing two sea-going flects to small units in order to constitute a Home Fleet which is not to be fully. manned, and from cutting down cruiser squadrons to only four vessels each, when experience shows that spreading practices with wireless telegraphy and searchlight signalling can only be efficiently exercised when six vessels take part. They claimed that a gain in strength would also be obtainal from kecping certain older ships in the sea-going flects, while the "Dreadnought" and several other modern vessels are in the Flome Fleet at Shcerness. The enunciation of such principles is subversive of the whole spirit of fighting Navies. The Standard announces that a number of battlo ships and armoured cruisers are to be placed in special reserve, or in the class on which no further repairs are to be executed. The neglect of obsolescent ships is justified if considerable attention is dovoted to new construction. If a nation is too poor to keep up a policy of replacement of old ships, she must, abovo all things, make the best of what she has got. She cannot have it both ways. (See Appendices $J, K, L, M$, for wastage and replacement tables.)

\section{Fonecasts.}

There were three forccasts in my paper in 1904. Ore was that the two-Power standard had not more than five years lease of life. The Prime Minister last July described the standard of France and Germany, and by inference that of either Power with the United States, as a "preposterous idea." The two-Power standard is spoken of is " a rouglu-and-ready guide," and this prompts the suspicion that an elastic standard is intended, and; when it can no longer be stretched, it will be broken. The second forecast was, that by careful attention to standardisation and organisation it would be possible to build ships in under two years instead of three years two months, as we were taking then. The other forecast I made was the expression of my hope that the cost of a battle-ship would "rise considerably all over tho world to about two millions sterling for each battle-ship." Sub. sequently the "IJord Nelsons" were laid down, to be followed by the "Dreadnoughts." One can only say now that the policy of initiating this development in ships is dependent for success on the courage with which it is pursued. There is an apparent lack of both courage and caution in the raluctions to which the country has recently been pledged. The reductions for next year are held out as ari example to the Peace Conference. One may safely venture on a fresh forecast, that no gain in the direction of disarmament will result from this Conference.

\section{The Peace Confenence.}

My 1904 paper pointed out the danger of Great Britain taking the initiative in a Conference for the limitation of naval armaments. 
The House of Commons this year passed a resolution calling on the Government " to take drastic steps to reduce the drain on national income, and to this end to press for the inclusion of the question of the reduction of armaments by international agreement in the agenda of the forthcoming Haguo Conference." It was accepted by the Governmont as a message to foreign Powers. Analyse it from this novel point, read the preliminary wail about the expenditure being. more than we can sustain, and then imagine such a document handed to Prince Buclow! What conclusion can we come to but that it was a tearful begging letter to the nations that Great Britain was at the end of her tetlier, and would they be so hind as to get us out of our difficulties? It is unnecessary to restate the objections urged in my paper, for the whole subject has been much more fully threshed out in both Houses of Parliament; but it is permissible to point out that everybody is willing to discuss the question of disamament. I hold, however, that the initiative ought not to be taken by Great Britain.

\section{Wasteful Duplication of Expenditure.}

In the 1904 paper it was pointed out how the Army tended to to over again tlie Navy's work.

What is sometimes called a second line of defence is really a duplication of expenditure and the dispersion instead of concentration of fighting force. This was the direction in which economy was urged. To everything the question was to be addressed: Are you vitally necessary or are you merely supposed to be useful? Only what is vital should be kept. Bases and forts could be abandoned, garrisons cut down, and tho Army and Militia organised for service abroad. The economy could, however, only be achieved through the certainty of naval supremacy. That is to say, no mere equality with an enemy would suffice, but we must have a safe working margin of superiority. An official return obtained by Sir John Colomb in 1903 showed in round numbers that 141 millions sterling per annum went to immobile defence. Of this amount nearly 10 millions was for the forts along our 43,000 miles of coast line. Reckoning interest on first cost, manning, stores, repairs, and replacement for a 20 years' life, the $£ 2,000,000$ battle-ship would cost $£ 250,000$ per annum. Two millions would therofore give us eight extra "Dreadnoughts," and with them Sir Arthur Wilson could have cornered his opponent last manouvres in less than a wcek. That is with one-fifth of the sum now spent on defending ports, many of which nobody would dream of attacking.

\section{Arsy Policy.}

One thing, horever, is certain. We cannot have it both ways. IVe cannot abandon shore defences against invasion and at the same time weaken the Navy that makes the economy possible. Let us take stock of the new responsibilities thrust upon the Navy as the result of the Blue-rater School's triumph :-

1. Mr. Brodrick's Army scheme originally provided for 435,000 men to defend us against invasion.

2. In $1905 \mathrm{Mr}$. Balfour postulated for a military force to ovcrcome an invasiou of 70,000 men.

3. In $1906 \mathrm{Mr}$. Haldane accepted bluc-water principles and threw the wholo responsibility of protecting the country against invasion on the Navy. 
An Immediate Strining Fonce.

Mr. Haldane's memorandum of 30th July says :-

"To sum up, the Government's proposal is that effort shall in future be mainly concentrated on the production of an expeditionary force immediately available for use over-seas in war."

Obviously such a force cannot cross the seas in war except under the protection of a predominant Navy, and one whose predominance exists under the military policy of the Government from the very outbreak of the war. For the same reason even our land frontiers, such as the 5,700 miles of Indian frontier, must be prepared at inordinate cost, unless the Navy can guarantee reinforcements. Yet the same day as Mr. Haldane issued his memorandum, Lord Tweedmouth explained in the House of Lords that the naval reductions were made because he brouglit before the Sea Lords the necessity of economy! The result was not a mere return to the normal, following on inflated Estimates; it was a reduction on top of a reduction. We were the only Power througliout the world that had diminished naval expenditure after 1904, in our case to the extent of five millions sterling. To achieve this we cut down stores and repairs, and framed a minimum programme of four armoured ships. (See Appendix A.) Then, having lost the "Montagu," having seen new programmes sanctioned by France and Germany in the spring, having multiplied the military responsibilities of the Navy indefinitely, "we are promised lhuge reductions of the naval programme for two ycars, carrying us far below the combined shipbuilding expenditure of either Germany and the United States or Germany and France. (See Appendix Y.)

\section{EXPENDITURE.}

I doubt whether it is clearly understood where theso naval reductions aro carrying us. All expenditure on armaments is relative. In the three years ending 1907-8 the relative increase of the German Navy Estimates, compared with our own, will be at least ten millions sterling. (See Appendix Z.)

Anyone acquainted with the temper of the majority in the present IIouse of Commons knows that the reductions are looked upon as permanent. The Socialist view is that the money is to be permanently used for social reform, and the official Liberal view is to apply it to the relief of taxation. Consequently, if our Navy Estimates are to stand still at the position of 1907-8, we have to take into consideration the further rise of the German Estimates provided for of $£ 1,534,000$ by 1909 . Here, then, is a relative increase of $11 \frac{1}{2}$ millions sterling.

'I do not wish to burden the paper with too much detail, but it should ba mentioned that we have recently withdrawn the troops from tho West Indies, Halifax, Esquimault, Trincomalee, St. Helena, and Wei-Hai-Wei. Wo have reduced the garrisons at Gibraltar, Malta, Mauritius, and elsewhere, abandoned systems of defence by submarine mines and Brennan torpedoes, and withdrawn dockyard stores and machinery from several over-sea yards. Tho Admiralty have officially explained that " if war broke out we could at once send out the necessary men and machinery." Of course, under protection of the reduced Nary-C.B. 


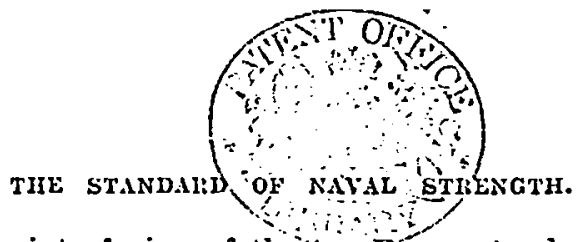

From the point of view of the two-Power standard, there are no compensations to be found elsewhere, either in France or the United States, for both nations are largely increasing their Estimates, while our own are decreasing. Since 1904 the American naval expenditure has increased by $£ \overline{5}, 416,000$, and the French by nearly half-a-million sterling, with the bulk of the increase to come next year. It cannot be contended that our example has had happy results. In Appendix $Y$ it will be scen that our expenditure on shipbuilding, repairs, and armaments is likely to fall $3 \frac{1}{2}$ nillions sterling below the combined expenditure of France and Germany on the same items. In 1893, under Mr. Gladstone, we had a new construction expenditure $\mathcal{E 2 , 2 1 0 , 0 0 0}$ lower than France and Russia. What was the result? In 1894 the biggest programme on record, and a new construction expenditure in 1896 of $£ 7,327,000$, or $4 \frac{1}{2}$ millions more than in the year of economy.

\section{Theories on inimcir Renuction is Defended.}

It is now time that we examined the arguments which have been advanced in favour of reduction. I know of no more foolish contention in our naval discussions than the plea which has been advanced by civilians like Lord Eversley, that tomage is an accurate measurc of fighting strength. On this ingenious and almost childish theory Lord Eversley arrives at the conclusion that all our "Royal Sovereigns" are first-class battle-ships, and that Germany has no first-class battle. ships built or building. Compound armour being such that it takes 5,000 tons to give the same results as 2,000 tons of Krupp armour; still the cxtra 3,000 tons is so much extra fighting power. So with the thousands of extra tons of coal and wood sheathing carried by our ships. The "Asama" of 1898, which did so well in the recent war, is to be reckoned the inferior of the "Ient," because, forsooth, she is $\mathbf{1 0 0}$ tons less displacement; yet she carries two inches more of armour and mounts two extra 8-inch guns. The tonnage theory, which has never been advanced by a responsible naval officer, amounts to this, that we, are to add up the mistakes of the past on the balance side as though they were miracles of common sense, and we are to go into action with as vast an aggregation of tonnage as the Russiaus did at Tsushima. I may tell these gentlemen that in naval administration, as in the administration of private affairs, the great art is to cut one's losses, and in that class we must reckon many thousands of tons of so-called war-ships.

\section{Tine Maigin of Safety.}

There is another maxim in business, and that is, always to work with a margin of safety. I have seen only one sensible argument for a weakened Navy. It is, that on the day of battle a single Power has an undoubted tactical advantage over allied Navies. The view, however, neglects strategical considerations. Supposing a war with France, Germany intervenes. Can we neglect the North Sea because we are fighting another nation in the IIediterrancan? The provision of force has to be the same as if we were fighting two flects of the same nation. What the advocates of naval reduction never realise is, that the problem of naval war for Great Britain is essentially different and more difficult than that presented to con- 
tinental wations, such as the United States, Germany, France, or Russia, to whom sea-power is not a vital necessity. For Great Britain must keep opcin all her sea roads by a continuous occupation of the sea, so as to prevent the arrest of her commerce and industry through sudden and violent incursions of tho enemy. For perbaps 360 days out of 365 in the year, she must go on with all the difficult drudgery of absent ships coaling, refitting, convoying, the heartbrcaking accidents of navigation, and all the vexatious precautions of the sea which are not fighting, but which are yet essential to the avoidance of disaster, when: the day for fighting comes.

\section{International Law and Neutrals.}

It is for the reasous I lave mentioned, chief among which is the coaling difficulty, tliat it is an accepted maxim among foreign stratecrists that 30 of thoir battle-ships are the equivalent of at least 40 British battleships. Hitherto, we lave always hoped that the coaling difficulty would seriously curtail the power of commerce destroyers to evade our awn cruisers. The declarations of the Powers during the recent war, and the actual coaling of the Russian ships, have not shown such a rigid interpretation of neutral obligations as we had anticıpated. Our only lope, beyond the Hague Conference, lies in our own strength in cruisers, and $I$ commend to your study the remarks in Appendix $V$. At the same time, let me strongly insist that questions with neutral Powers will be apt to arise with even more frequency thai .in the past, and as a belligerent we cannot hope to impress our vicis unless we have a reserve of strength as when we sent a fleet to Copenhagen without dininishing our blockading fleets. The reserve of strength is not only the visible means which strengthens our diplomacy during peace, so that peace tends to be preserved, but it is the only means we liave when beset by war's difficulties, of maintaining a firm front in face of neutrals. It is only a few months ago that our. whole Mediterrancan force was ordered to overawe a nation without any. Navy at, all.

\section{Losses Due to Navigation.}

The past cannot teach us much about the coaling difficulty, to which we have referred, except in so far as incidents connected with provisions and water bear on the matter of supplies as when Nelson parted with six of his battle-ships the day before Trafalgar. History, however, can tell us much concerning losses through accidents which are not due to battle. The ordinary losses through accidents of navigation were abundantly illustrated prior to the battles of St. Vincent, the Nile, and Copenhagen.

Between 1793 and 1802 , or a period of 9 years, we lost through causes other than war, 64 sail of the line and frigates, as compared with 19 for the allies, France, Spain, and Holland, or over four to ouc. Even now, when British ships do not spend more than a quarter of their time at $s \in a$, we find such incidents as over half the Mediterrancan battle-ships unavailable on receiving the order to proced east for the coercion of Turkey, and after delays, only five out of the eiglit battle-ships were on the scene of possible hostilities. Within the last few montlss we have had the deplorable loss of the services for a time, or for all time, of the "Montagu," "Duncan," 
"Dominion," "Prince of Wales," "Hindustan," and " Ramillies," while four other battle-slips had to part company from their fleets in the manouvres through engine-room defects. The "Africa" was nearly piled up on the "Lizard" in a fog. The "Prince George," "Renown," and "Mars" grounded, the " Drealnought" damaged when entering Portsmouth basin, and the "Illustrious" in collision, complete the list of minor accidents for the year to our battle-ships. Other battle-ships, like the "Glory" and the "Ocean," have been a perpetual drag on their flects.

\section{INVENTION.}

It is invention which enhances the need of constant watchfulness as to the maintenance of our naval supremacy. The mere.introduction of turbines with their large consumption of coal means that ships will be oftener absent from their fighting positions, while water-tube boilers need more constant renewals. Turbmes have suddeuly increased the speed of all new commerce destroyers; as against all our existing cruisers with reciprocating engines. The accuracy and rapidity of modern gun-fire, enabling particular portions of the hull to be hit succestiully, and the development of shell-fire has made the unarmoured ends of 34 out of 60 British battle-ships, the Achilles heel of the British Navy. (See Appendix B.) The German North Sea Fleet of 16 battle-ships, will have, for instance, 256 quick-firing guns, 6-inch and above, as compared witl 158 in the secondary batteries of the 14 battle-ships in the new Chamnel Fleet, and though we have put the nine available battle-slips which have complete belt protection into the Channel, there are still left five with unammoured ends for 256 guns to play upon.

Wireless telegraphy assists us provided there are enough vessels carrying the instruments, so as to spread our net as widely as possible. (See Appendix V.; dealing with the Admiralty statement virtually admitting that if we do not at once lay down a number of cruisers we shall have only the 3 "Invincibles" and 35 armoured cruisers at our disposal as cruisers.)

The gyroscope has undoubtedly increased the range and accuracy of torpedoes, so that 4,000 yards' range is now almost practicable, and consequently, the rislss to ships, the need of both a margin of safety in numbers of armoured vessels and of destroyers, to make it hot for the enemy's torpedo craft, has been increased. (See Appendix IV, dealing with destroyers.) The adrocacy in Germany of the practice of the Russo-Japanese War, of laying mines on the open sea, introduces a factor in the North Sea by which Japan lost one-third of her battle-ship strength in the recent war. It is to be hoped that the Haguo Conference will settle this point, which is of far more importance than wasting our efforts after unattainable ideals.

\section{Relative Strength.}

I now come to the most controversial part of my paper, our actual relative strength judged by the rule Lord Cawdor says has existed for years at the Admiralty, of a very large superiority in cruisers over any two Powers, and a ten per cent. margin of superiority. in numbers of effective battle-ships ovor any two Powers. In the Appendix I have had recourse to almost every authority, and to a 
number of comparisons of my own. In every case I find that when we allow for ships ;building and projected, we are falling below the two-Power standard. The most interesting tests are those according to age (Appendix I.), and the test by gun armaments measured by the capacity of the guns to fulfil their office of breaking down the armour of an enemy's ship. (Appendix H.) I have left out the United States in the case of the guns, for if included as one of the two Powers we should be hopelessly below the standard. The table ${ }^{-}$is open to criticism, on the ground that it makes no allowance for any superiority of gun platforms. It is only when taken in conjunction with other data in the Appendix that $\mathbf{I}$ believe we find overwhelming evidence that the reductions of our shipbuilding programme for next year aro not justified.

\section{Considerations Governing Policy.}

Ruling out the United States for purposes of argument, we are left with France and. Germany to consider. In Appendix $D$ it is shown that the speed at which individual ships are built in Germany is level with our own. On the other hand, French shipbuilding has been so demoralised by Socialistic interference that if ships are laid down now, or, say beforc next March, we need not provide for them until our programine of 1908-9. The limitation to this argument is, that it is grossly extravagant for us to lay down threc ships one year and nino the next. I propose now to see how we stand in regard to the opinions of the expert advisers of the nation as enunciated when they laid down our minimum requirements last November. Their calculation was based on the ships then building in France and Germany. In that year, 1905-6, we had laid down four armourcd ships to three for Germany and none for France. In the spring of 1906, Germany sanctipned an additional armoured ship; while in July we postponed oxe armoured ship, owing, as Lord Tweedmouth has told us, to his impressing on the Board the need of economy. The dat after Parliament adjournod, the Admiralty announced the complete loss of the "Montagu." Thus, apart from any question of replacing the five "Admiral "class which have been set aside this year, or the fourteen battleships which are about to follow the "Admiral" class in that dismal procession of vetel ans, to the graveyard, we have three armoured ships to build in the programme of 1907-8.

As Germany builds as fast as we do, and, except in the present year (1906), has invariably laid down her programme before our own, we must, in our programme for 1907-8, add in her provision of 3 armoured ships for 1907-8. This makes $6^{\circ}$ armoured ships for 1907-8, instead of the 3 we propose to lay down, or 7 if we desire to have any margin. In 1908-9 we have Germany's provision of 3 armoured ships to consider, and the French programme of 6 armoured ships, sanctioned this year, which will, by that time, be well advanced; in other words, 9 armoured ships, for which 10 must be laid down to give us a margin. The programmes then would be:-

$\begin{array}{cccccccc}1905-6 & \ldots & \ldots & \ldots & \ldots & 4 \text { armoured ships. } \\ 1906-7 & \ldots & \ldots & \ldots & \ldots & 3 & , & , \\ 1907-8 & \ldots & \ldots & \ldots & \ldots & 7 & ", & " \\ 1908-9 & \ldots & \ldots & \ldots & \ldots & 10 & \#,\end{array}$


Thers remains 1909-10, for which Gernany will again lay down 3 armoured ships. If, now, we assume France lays down no additional armoured ships for 1907 or 1908 , we can be content with 3 or perhaps 4 armoured ships in 1909-10. These are great fluctuations, whereas an average of the whole' of these programmes for the fivo years gives five armoured ships per annum-a figure that exactly corresponds to the average wastage of our armoured ships given in Table if It does not realise the ideal of those who advocate laying down two ships for each oue Germany starts, which was, as Sir Edward Grey has pointed out, our old policy in regard to France.

I leave it to the meeting to judge whether it is better to have a steady output, as in Germany, - ofring regular cmployment, or a scaro programmo in 1908.

\section{INDEX TO APPENDICES.}

A.-This year's Navy reductions in tabular form.

B.-Battleship's with unarmoured ends.

C.-Distribution of British Navy in 1906.

D.- Rate of building, Great Britain anxl Germany.

E.-The Navies in 1917.

F.-Years of anxiety. Our Navy in 1888, 1894, and 1906.

G.-Programmes of the Powers, 1900-7.

H.-Comparative strength by efficiency of guns.

I.-Comparative strength by age of battle-ships.

J.-Number of ships building for Royal Navy, 1900-6.

K.-Shipbuilding activity of Powers in 1901 and 1906.

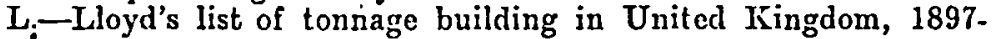
1906.

M.-The wastage of our ships through obsolescence, 1900-6.

\section{Relative Strengtir.}

N.-Naval Annual's estimate.

O.-Estimate of "Fighting Ships."

P.- Naval Pocket Book's Estimate.

Q.-Estimate of the "Royal Navy List."

R.-Navy League's comparisons.

S.-General criticism of the Return of Fleets (Great Britain and Foreign Countries).

T.-German programmes; 1906-1917.

U.-Prince Buelow's standard.

V.-British cruisers.

W.-British destroyers: Relative strength.

$X$.-British expenditure on new ships for 20 years.

Y.-Relative shipbuilding expenditure.

Z.-Relative British and foreign expenditure.

\section{APPENDICES.}

A.-Tine Reductions Announced 27 Tir July, 1906.

The extent of the reductions for two years is best shown in tabular form, as the statement has been repeatedly mado that the amount is small :- 


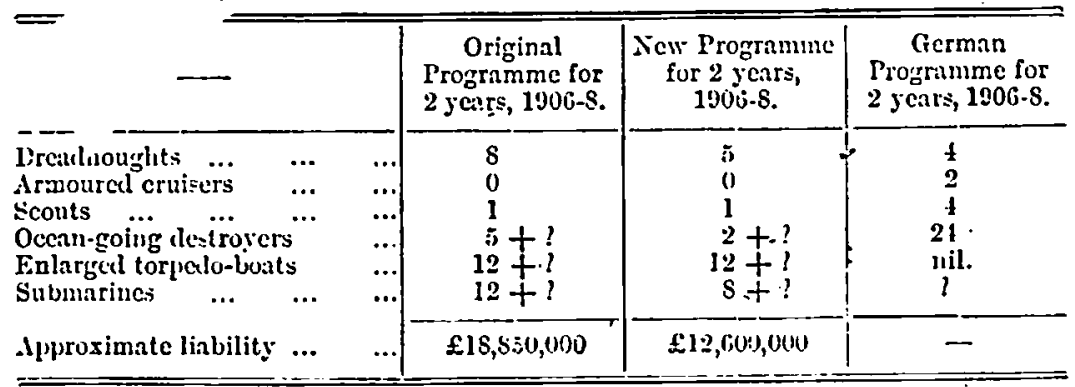

(The abovo compares with an outlay of $£ 21,146,000$ for 1903-5. If the Hague Conference is decmed to have failed, one more armoured vessel will be laid down.)

\section{B.-Battleshirs. \\ Unarmoured Ends.}

As this question is one of the gravest that can possibly come before the country, it is necessary that every civilian should uuderstand that the phrase means no armour protection to the bow and stcrn at the water-line, so that shell-fire can tear huge holes. The following analysis in respect of armour protection to the water-line deals only with ships classed as first-class in the official return:-

France and Germany.-Complete belts for all battle-ships.

Gricut Brituin.-34 first-class battle-ships have both ends unarnoured.

13 have unarmoured stcrus.

13 most modern have complete belts.

At the battle of Port Arthur the "Poltava" was put out of action by a hit on the unarmoured bow.

At the battle of Tsushirna, Russian battle-ships with unarmoured parts in contact with the waterline were sunk by gun-fire. $\Lambda$ fter the receipt of all our Naval 'Attachés' reports on the battle of Tsushima, the memoraudum on Admiralty Policy was issued last November on the advice of the present Sea Lords. In it is the grave statement that if $£ 2,000,000$ were spent on the armaments, etc., of the "Admiral" class of battle-ships, their unarmoured ends would still leave them vulnerable to a second-class cruiser.

\section{C.-Dispersion versus Concentration.}

Figures for 1906 to show the dispersion of British force abroad. In 1902-3 the Navy reached its maximum of dispersion. . The degree of dispersion is dependent on policy, and the more fortunate state of affairs, in 1906 and 1907, cannot be expected to last indefinitely :-

\begin{tabular}{|c|c|c|c|}
\hline$\longrightarrow$ & $\begin{array}{l}\text { At llome on } \\
\text { Commission or } \\
\quad \text { liescrre. }\end{array}$ & Abroari. & Cruising. \\
\hline Battle-ships & 20 & 16 & - \\
\hline $\begin{array}{l}\text { Armourch cruisers,including "I'ower- } \\
\text { ful" and "Diatlem" clissos }\end{array}$ & 20 & 15 & - \\
\hline Jargetirotected eruiscrs & 10 & $\mathbf{S}$ & 10 \\
\hline Small protected cruisers and scouts ... & 1.8 & 15 & - \\
\hline Destroyers & 9.3 & 47 & - \\
\hline
\end{tabular}


The following addition has been made subscquent to the lecture.)

In a criticism on the lecture in a paragraph dealing with tha distribution of ships, lynginecring says, of the ships with nucleus crews on board, that "experience has shown that upon orders being issued suddenly during the night, three hours sufficed for the ressel to be made ready to depart for war." I immediately took steps to ascertain the position, at the nearest dockyards to the North Sea, Chatham and Sheorness, which would furnish the nearest force, the Channel Fleet being at Vigo. There was not a single ship in full commission outside Chatham Basin except the cruiser "Black P'rince." The old battle-ships "Magnificent" and "Rojal Oak" also lay in the Medway with nucleus crews on board, as also two protected cruisers, two torpedo gun-boats, twelve destroyers, and five torpedo-boats. In Chatham Basin there were crowded tho following:-

Rattle-ships.

Ship: in full Conmission.

Shijs with Nuclens Crews.

"Africa."

"Ocean."

"Albemarle."

"Albion." .

"Ramillies."

"Repulse."

"Resolution."

$\cdot$

"Roxburgh."

"Sutlej."

"Cumberland."

"Dido."”

"Leander.".

"Pathfinder."

18 destroyers.
Armoused Cruisers.

"Bedford."

"Leviathan."

l'rotected Craisers.

"Amphiţrite."

"Andromeda."

"Argonaut."

"Blenheim."

"Charybuis:"

" Edgar."

"Scylla."

"Thetis."

Scouts.

"Adventurc."

"Attention."

6 torpedo-b̈oats.

Torpedo Gun-boat.

"Speedwell."

Engineering leads the nublic to believe that these ships can get to sea in three hours. What are the facts? The ships could not possibly assemble in the Medway in under a week, even if they have the luck to escape fogs. Only tuo large ships can go out of Chatham Basin at one tide, and the river is not lighted for pilotage at night. time. The Atlautic Fleet is dispersed at the three dockyards with laalf the crews on leave. 
It is in face of this state of anairs that the public are led to believe that in the event of a sudden crisis the ships could be assembled in overwhelming force in three hours.

Another point that needs emphasising is, that both with nucleus crews and two year commissions a large number of crews are in an imperfect state of training. Thus, out of our 60 nominal first-class battle-ships, only 26 havo been in full commission for the whole of 1906 , and of our 38 armoured cruisers built, or btilding, only 14 have been in full commission for the whole of this year.

\begin{tabular}{|c|c|c|c|c|c|c|}
\hline \multicolumn{5}{|c|}{-} & 1801. & 1900i. \\
\hline $\begin{array}{c}\text { Number of } \\
"\end{array}$ & $\begin{array}{l}\text { fighting ships abroul } \\
\text { armourel }\end{array}$ & $\begin{array}{l}\ldots \\
\ldots\end{array}$ & $\begin{array}{l}\cdots \\
\cdots\end{array}$ & $\cdots$ & 17 out of 73 . & - $\begin{array}{c}127 \\
31 \text { out of } 77\end{array}$ \\
\hline
\end{tabular}

Practically the whole German Navy is concentrated in easy reach of the North Sea.

\section{D.-Rate of BLildiNg.}

From date of laying down to date of completion for commissioning :-

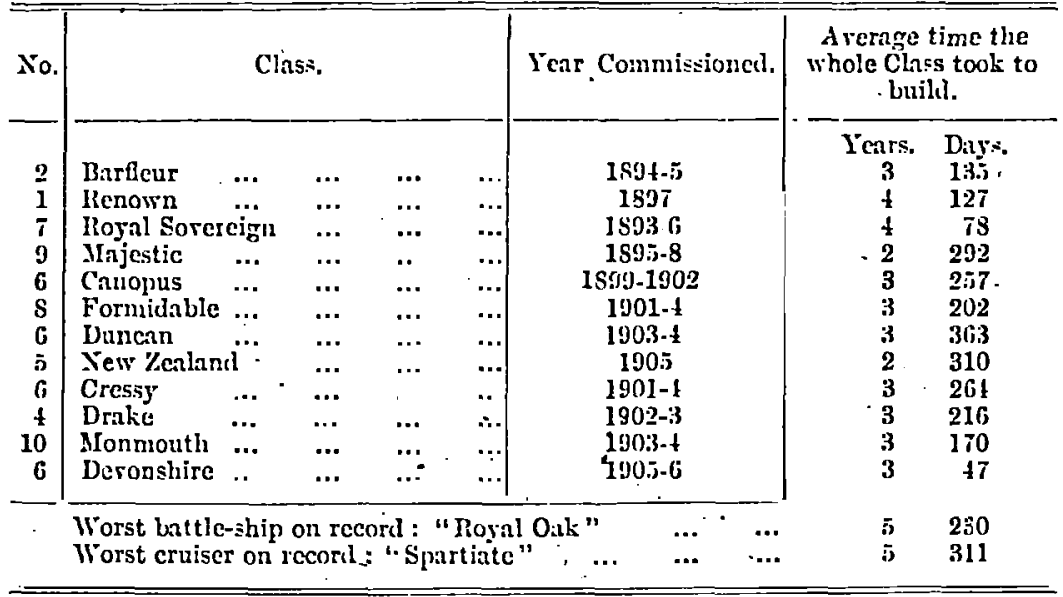

It will be seen from the time taken over the small "County" class of cruisers that the question of the displacement of a vessel exercises little influence on the time taken to build.

The following official figures as to German first-class battle-ships may be usefully compared with the above table, as showing that we possess no inherent advantage in the rapidity with which the annual naval programme can be completed:-

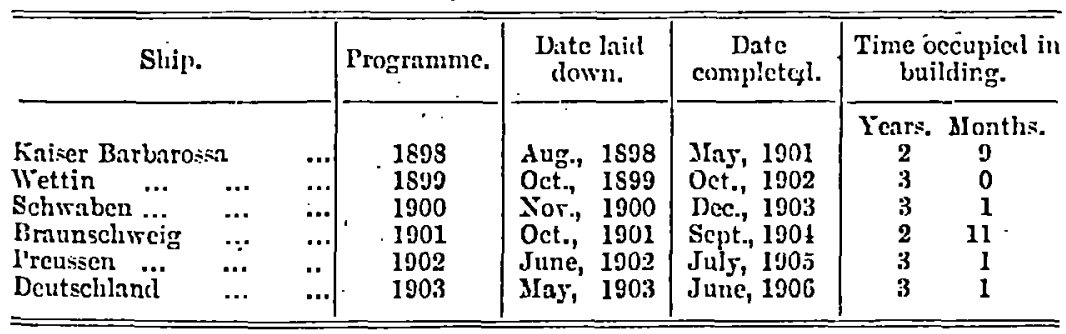




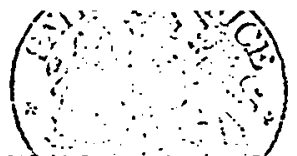

TIE STANDARD OP NAVAI STRENGTH.

German ships are not regarded as completed until after the committee, on war-ship trials have finished their task, and left the ship for good. It is noticeable that the German ships are laid down in the year of their programme, instead of being delayed into the following year, as is so frequently the case with our ships.

\section{E.-The Navies in 1917.}

The United States, like ourselves, has no fixed programme for a number of years ahead, but she can always be relied on to kecp ahead of Germany, especially as she has to distribute her ships between the Pacific and Atlantic.

Both Franco and Germany have mapped out programmes to the year 1917, but whereas that of Germany is settled, the one for France is subject to capricious changes. The following table gives the tate of navies if the programmes are adhered to:-

\begin{tabular}{|c|c|c|c|c|c|c|}
\hline$\longrightarrow$ & & & & France. & Germany. & $\begin{array}{c}\text { Two-Power } \\
\text { Standard. }\end{array}$ \\
\hline $\begin{array}{l}\text { First-class battle-ships. } \\
\text { Armourel cruisets } \\
\text { Scouts and small cruisers } \\
\text { Destroyers ... ... } \\
\text { Submarincs for attack } \\
\text { Submarines for defenec } \\
\text { Torpedo-bonts ... }\end{array}$ & $\begin{array}{l}\ldots \\
\ldots \\
\ldots \\
\ldots \\
\ldots\end{array}$ & $\begin{array}{l}. . \\
\cdots \\
\cdots \\
\cdots \\
\cdots \\
\cdots\end{array}$ & \begin{tabular}{l|}
$\cdots$ \\
$\cdots$ \\
$\cdots$ \\
$\cdots$ \\
$\cdots$ \\
$\cdots$
\end{tabular} & $\begin{array}{c}31 \\
19 \\
6+? \\
109 \\
82 \\
10 \\
170\end{array}$ & $\begin{array}{r}38 \\
20 \\
38 \\
1+8 \\
? \\
? \\
?\end{array}$ & $\begin{array}{c}\text { So (10\% margin) } \\
\text { s0 (2i\%," }) \\
? \\
? \\
?\end{array}$ \\
\hline
\end{tabular}

Counting all vessels laid down in 1900, and subsequently as efficient in 1917, we shall have 19 , leaving 61 to be laid down in the ten years, 1908-17, inclusive. That is to say, to keep up the twoPower standard we should 'require 6 "Dreadnoughts" per annum, at least one armoured cruiser, and other cruisers. The possibilities of economy lie in any inability of France to face the expenditure necessitated by the above programme. The calculations of France and Germany are admittedly based on the idea that some ships laid down prior to 1900 will be reconstructed. Should Great Britain abandon her present policy of abstaining from all efforts at reconstruction, then the lives of vessels will be prolonged and ships laid down before 1900 can be included. The incsitation about reconstruction is duo to the inherent defect of unarmoured ends in these vessels. (Vide Table B, and Cawdor Memo. of 1905, p. 31.)

\section{F.-Years of Anxiety.}

The three most recent years in which there has been great anxiety about the future position of tho Navy wero 1888, 1894, and the present year. The following table gives our position in each year, according to official returns with the following alterations:-

1. Return No. 12, June, 1888, No. 218.-All wood hulls have been excluded, as well as six British battle-ships requiring large repairs.

2. Return No. 129, 24th April, 1906.-Vessels not being main= tained are excluded. The French armoured cruiser "Vauban" has been excluded from this list, and all 
French and German unprotected cruisers. The "Royal Sovercign," "Nile," "Trafalgar," "Centurion," "Barneur," and the "Renown," used as a yacht, are iucluded, though it is frecly rumoured that with the exception of the "Renown," it is not the intention to spend any more money on maintenance.

\begin{tabular}{|c|c|c|c|c|c|c|c|c|}
\hline \multirow[b]{2}{*}{$\begin{array}{l}\text { Built } \\
\text { and Building. }\end{array}$} & \multicolumn{3}{|c|}{1885.} & \multicolumn{3}{|c|}{1891.} & \multicolumn{2}{|c|}{$\begin{array}{l}1906 . \\
\text { (Built, building } \\
\text { and projected). }\end{array}$} \\
\hline & 点总 & 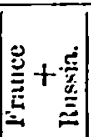 & 咅十 & & 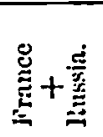 & 总离 & 莣焉 & 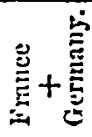 \\
\hline $\begin{array}{cc}\text { Battle-ships. } & \\
\text { list Class } & \ldots \\
\text { 2nd Class } & \ldots \\
\text { 3rt Class } & \ldots\end{array}$ & $\$ 1$ & 26 & 29 & $\left.\begin{array}{l}22 \\
12 \\
11\end{array}\right\} 4$ & $\left.\begin{array}{r}25 \\
21 \\
6\end{array}\right\} 52$ & $\left.\begin{array}{l}22 \\
20 \\
12\end{array}\right\}=1$ & $\left.\begin{array}{r}5 i \\
0 \\
0\end{array}\right\} 57$ & $\left.\begin{array}{l}37 \\
13 \\
10\end{array}\right\} 80$ \\
\hline $\begin{array}{l}\text { Coast -defence } \\
\text { ressels of orer } \\
2,000^{\circ} \text { tons and } \\
\text { more than onc } \\
\text { lieavy gun. }\end{array}$ & 11 & 19 & 8 & 15 & 20 & l; & 0 & 3 \\
\hline Armoured cruiscrs & 12 & $\mathbf{9}$ & 2 & 15 & 20 & 9 & 33 & 32 \\
\hline Other cruisers ... & $\pi i$ & it & Sij & 113 & 67 & 91 & 71 & $\pi 1$ \\
\hline
\end{tabular}

So far as this table affords any indication, it is that our position is at the least about to become as bad as in 1888 or 1894 , when the Chambers of Commerce took action.

\section{G.-Programies.}

It may be said that our large superiority in older ships, oning to the building efforts up to 1900 , kept us at the two-Power standard until 1905 or 1906 . With the advent of entirely new types with much heavier armaments, it becomes dangerous to rely on these old types, especially as wo have scen they have all got unarmoured ends. The following table shows the programmes of the Powers in firstclass battle-ships:-

\begin{tabular}{|c|c|c|c|c|c|c|c|c|c|}
\hline$\cdot$ & 1000 & 1001 & 1902 & 1903 & 1901 & 1905 & 1906 & 1907 & Total. \\
\hline $\begin{array}{l}\text { Great Britain (23) .. } \\
\text { Gurmany (13) } \\
\text { United States (15) ... } \\
\text { France (10) ... }\end{array}$ & $\begin{array}{l}2 \\
2 \\
2 \\
2\end{array}$ & $\begin{array}{l}3 \\
2 \\
0 \\
0\end{array}$ & $\begin{array}{l}2 \\
2 \\
2 \\
1\end{array}$ & $\begin{array}{l}3- \\
2 \\
5 \\
0\end{array}$ & $\begin{array}{l}4 \\
2 \\
1 \\
0\end{array}$ & $\begin{array}{l}1 \\
2 \\
2 \\
0\end{array}$ & $\begin{array}{l}3 \\
2 \\
1 \\
3\end{array}$ & $\begin{array}{l}2 \\
2 \\
2 \\
3\end{array}$ & $\begin{array}{l}20 \\
16 \\
15 \\
12\end{array}$ \\
\hline
\end{tabular}

Thus our total of 20 battle-ships compares with 31 for Germany aud the United States, and 28 for France and Germany.

The figures in brackets show the number of first-class battle-ships which will be kess than 18 ycars old at the end of 1907 , which are not included in the above table of programmes. 
As regards "Invincibles," of which so much has been said, we shall have three in 1910, to two for Germany, two for the United States, and none for France.

It inay be contended that we should classify in "Dreadnoughts"; battle-ships with 8 -inch guns and above in their secondary armaments; and lastly battle-ships of earlier types.

Our table then reads as follows:-

\begin{tabular}{|c|c|c|c|c|c|c|}
\hline$\cdot$ & & & & $\begin{array}{l}\text { Fighting } \\
\text { equiralent of } \\
\text { Drendlnoughts. }\end{array}$ & Intermediates. & Earlier Types. \\
\hline $\begin{array}{l}\text { Great Britain } \\
\text { Germany } \\
\text { United States } \\
\text { France ... }\end{array}$ & $\begin{array}{l}\cdots \\
\cdots \\
\cdots \\
\cdots\end{array}$ & $\begin{array}{l}\cdots \\
\cdots \\
\cdots\end{array}$ & $\begin{array}{l}\cdots \\
\cdots \\
\cdots \\
\cdots\end{array}$ & $\begin{array}{l}S^{\prime} \\
4 \\
5 \\
6\end{array}$ & $\begin{array}{c}\text { s } \\
\text { Xil. } \\
13^{2} \\
\text { Nil. }\end{array}$ & $\begin{array}{c}4 \\
10 \\
\text { Nil. } \\
6\end{array}$ \\
\hline
\end{tabular}

IIncludes trro "Lord Nelson's."

2 Includes threo intermodiatos, not in the first table, the United States having initiated the policy.

This still leaves us well below the two-Power standard in the future, but it improves the position considerably as against Germany. Two of our "Dreadnoughts" will not bo laid down until March, 1908, whereas all four for Germany will then have been.building for sonre time, and Germany will, in $J$ une or July, 1908, lay down two more not included in the above table. These two will, however, be ready in 1910, and it is the position that year which should dictate our $1906-7$ and $1907-8$ programmes.

\section{H.-Compáarisons iy Guns.}

Strength, according to the efficiency of guns mounted in battleships or coast-defence vessels. Only guns of a theoretical perforation of 7 inches, or more of the best armour at 5,000 yards, with capped projectiles, according to the gun tables in Jane's "Fighting Ships," are included in this list, and it includes battloships to be laid down in 1906 and 1907. It is assumed from the Press reports that the German battle-ships will carry sixteen 11-inch guns, and corrections must be applied if wrong:-

\begin{tabular}{|c|c|c|c|c|}
\hline $\left.\begin{array}{l}\text { scorctical perforation of } \\
\text { Armour at } \tilde{\tilde{v}, 000} \text { jards. }\end{array}\right\}=$ & $17 l^{\prime \prime}$ to $18^{\prime \prime}$ & $14^{\prime}$ to $16^{n}$ & $11^{\prime \prime}$ to $13^{\prime \prime}$ & $\tau^{n}$ to $10 ! "$ \\
\hline 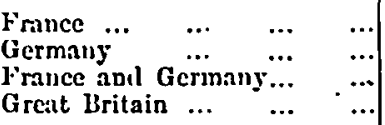 & $\begin{array}{r}10 \\
104 \\
101 \\
48\end{array}$ & $\frac{16}{16}$ & $\begin{array}{r}110 \\
40 \\
150 \\
40\end{array}$ & $\begin{array}{r}61 \\
10 \\
101 \\
40\end{array}$ \\
\hline
\end{tabular}

(In March, 1908, faccording to programme, 20 British guns, or possibly 30 , will be add d to column (1), making 68 or 78 guns capable of perforating $17 \frac{1}{2}$-inch armour.)

Il should be distlnctly understood that a very large number of British battle-ships lfave no armour at the water-line on the bow or 
stern, and the large secondary armaments in German batt ships, of which the above table takes no account, were given for the special purpose of sinking these battle-ships by rapid shell fire directed at their unarmoured ends.

\section{I.-Strengti According to $\Lambda \mathrm{ge}$ of Batthe-Siriss.}

Sir Ilenry Campbell-Bamerman:-"Are none of tho ships of the other Powers obsolescent?"-House of Commons, 27th July, 1906.\%

All first-class battleships built or building on 31 st December, 1907, Iess than

\begin{tabular}{|c|c|c|c|c|c|}
\hline Nation or Combination. & $\begin{array}{l}2: 3 \text { years } \\
\text { old. }\end{array}$ & $\begin{array}{c}18 \text { years } \\
\text { old. }\end{array}$ & $\begin{array}{l}13 \text { years } \\
\text { old. }\end{array}$ & $\begin{array}{l}8 \text { jonrs } \\
\text { old. }\end{array}$ & $\begin{array}{c}\text { Laid down } \\
\text { or projected } \\
\text { 1905-7. }\end{array}$ \\
\hline 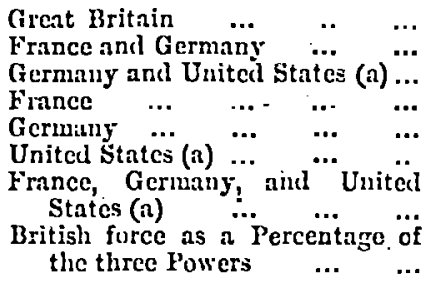 & $\begin{array}{l}58 \\
51 \\
56 \\
23 \\
28 \\
28 \\
70 \\
70 \\
\text { 13.c. } \\
73.5\end{array}$ & $\begin{array}{l}\overline{0} 2 \\
49 \\
55 \\
22 \\
27 \\
23\end{array}$ & $\begin{array}{l}37 \\
41 \\
48 \\
17 \\
21 \\
2 \pm \\
65 \\
65 . c . \\
56.9\end{array}$ & $\begin{array}{l}13 \\
28 \\
32 \\
12 \\
16 \\
16 \\
44 \\
13 . c . \\
43.2\end{array}$ & $\begin{array}{r}6 \\
12 \\
10 \\
6 \\
6 \\
4 \\
16 \\
\text { p.c. } \\
37.5\end{array}$ \\
\hline
\end{tabular}

(a) Does not include any programme for the United States in 1907, but four battleships are contemplated, and if this is correct, four should be added to cach column for United States.

- The rapid reduction in the British proportion of first-class battleships as we discard those laid down previous to 1895 , is explained by tho following table, from which the "Montagu" is, of course, excluded. The table shows first-class battle-sliips laid down by the Powers in the quinquennial periods named, and in a final period, 1905-7, gives the ships building or psojected for those three jears:-

\begin{tabular}{|c|c|c|c|c|c|c|c|c|c|}
\hline & & & & & 1SSE-3. & $1890-4$ & $1595-9$. & $1900-4$. & 1905.7. \\
\hline $\begin{array}{l}\text { Great Britain } \\
\text { France ... } \\
\text { Germany... } \\
\text { United States }\end{array}$ & $\begin{array}{l}\ldots \\
\cdots \\
\cdots \\
\cdots\end{array}$ & $\begin{array}{l}\ldots \\
\cdots \\
\cdots \\
\cdots\end{array}$ & $\begin{array}{r}1 \ldots \\
\ldots . \\
\ldots \\
\ldots\end{array}$ & $\begin{array}{l}\ldots \\
\ldots \\
\ldots \\
\cdots\end{array}$ & $\begin{array}{c}\mathbf{6} \\
1 \\
1 \\
\text { xil. }\end{array}$ & $\begin{array}{r}15 \\
5 \\
3 \\
4\end{array}$ & $\begin{array}{r}18 \\
5 \\
8 \\
8\end{array}$ & $\begin{array}{r}13 \\
6 \\
10 \\
12\end{array}$ & $\begin{array}{l}\text { (i. } \\
6 \\
6 \\
1(a)\end{array}$ \\
\hline
\end{tabular}

(a) Does not includo any programme for the United States in 1907. As stated clsewhere, four.battleships are contemplated.

Tho old ships that are used to swell the table of British ships are a danger and a delusion. TVe have-in the Returns of Flects (Great Britain and Foreign Countries) eight so-called first-class battle-ships launched prior to tho Naval Defence Act; France has seven, and Germany none. Of the seven French battle-ships, six had been reconstructed and the seventh is in hand. Of the eight British battleships, the "Nilc". and "Trafagar" are still maintained, and none of the ships have been reconstricted. The "Nile" and "Trafalgar" lave undergone alteratious to their secondary armaments. The

vol. LI. 
"Sans Pareil" and the five "Admiral" class have had a total sum of $£ 1,489$ spent an them during the last 18 months. After months of pretence concerning these vessels, the admission was obtained from MIr. Robertson on 7th November that "the expenditure $(£ 1,489)$ was not for the purpose of maintaining tho ships in a state of readiness for war, but with a view to their upkeep pending removal to the sale list next year.".

IVe have recluced the Royal Dockyards by $\$, 670$ men during the last five years, and of these nearly 7,000 went last year. Similar reductions have taken place at II'onluich and the private yards. The causes can be sought in the follouing four tables:-

\section{J.-Nuarber of Simps Under Construction.}

Ships of over 5,000 tons under construction for the Royal Navy on the 1st April, 1900, to 1st April, 1906, inclusive:-

\begin{tabular}{|c|c|c|c|c|c|c|c|c|c|}
\hline \multirow{2}{*}{$\cdot$} & \multirow{2}{*}{ Yeare. } & & \multicolumn{3}{|c|}{ Battle-sbips. } & \multicolumn{3}{|c|}{ Cruisers. } & \multirow{2}{*}{$\begin{array}{l}\text { Grand } \\
\text { Total. }\end{array}$} \\
\hline & & & $\begin{array}{l}\text { Dock- } \\
\text { yards. }\end{array}$ & $\begin{array}{c}\text { Con- } \\
\text { tractors. }\end{array}$ & Total. & $\begin{array}{l}\text { Dock- } \\
\text { yarils. }\end{array}$ & $\begin{array}{c}\text { Con- } \\
\text { tractors. }\end{array}$ & Total. & \\
\hline $\begin{array}{l}1900 \\
1901 \\
1902 \\
1903 \\
1904 \\
1905 \\
1906\end{array}$ & $\begin{array}{l}\ldots . \\
\ldots \\
\ldots \\
\ldots \\
\ldots \\
\ldots\end{array}$ & $\begin{array}{l}\ldots . \\
\ldots \\
\ldots \\
\ldots \\
\ldots \\
\ldots\end{array}$ & $\begin{array}{r}8 \\
10 \\
7 \\
6 \\
7 \\
4 \\
4\end{array}$ & $\mid \begin{array}{l}7 \\
6 \\
5 \\
6 \\
5 \\
4 \\
2\end{array}$ & $\begin{array}{r}15 \\
16 \\
12 \\
12 \\
12 \\
5 \\
6\end{array}$ & $\begin{array}{l}4 \\
8 \\
9 \\
8 \\
7 \\
7 \\
4\end{array}$ & $\begin{array}{r}12 \\
15 \\
13 \\
14 \\
8 \\
9 \\
7\end{array}$ & $\begin{array}{l}16 \\
23 \\
22 \\
22 \\
15 \\
16 \\
11\end{array}$ & $\begin{array}{l}31 \\
39 \\
31 \\
31 \\
27 \\
21 \\
37\end{array}$ \\
\hline
\end{tabular}

A verage numbers unler construction for 7 years $=30$

Anticipated numbers umler construction on

completion of three "Invincibles" pind after $=$ (Of these, two may be

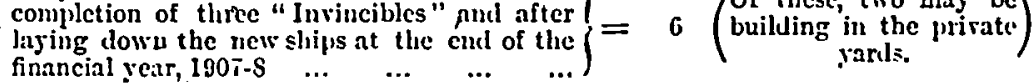

\section{K.-Battle-ships Building and Projected on 1st April, 1901 AND 1906.}

$\begin{array}{lcccc} & & 1901 & 1906 & \text { Present day. } \\ \text { Great Britain } \cdot \ldots & \ldots & 19 & 9 & 6 \\ \text { France and Germany } & \ldots & 15 & 20 & 19 \\ \text { France and United States } & 15 & 25 & 21 \\ \text { Germany and United States } & 22 & & 21 & 16\end{array}$

In 1907 Germany will lay down two additional battle-ships and the United States probably two.

\section{L.-Warships Building in UNized Kingdom for all Countries.}

The following table has been kindly furnished by Lloyd's Register of Shipping:-

Number and displacement of war-vessel: under construction in the United Kingdom at the end of September, 1897-1906, according to 
the Returns published by Lloyd's Register of British and Forcign Shipping :-

$\begin{array}{rrrrrr} & \text { No. } & \text { Tons. } & & - \text { No. } & \text { Tons. } \\ 1897 & 87 & 318,612 & 1902 & 58 & 303,202 \\ 1898 & 92 & 376,435 & 1903 & 64 & 327,570 \\ 1899 & 82 & 412,980 & 1904 & 67 & 342,930 \\ 1900 & 69 & 427,855 & 1905 & 42 & 264,310 \\ 1901 & 50 & 375,045 & 1906 & 47 & 203,345\end{array}$

The maximum reached was in March, 1900, when 450,000 tons were in hand.

M.-The Vistage List.

Sliips of over 4,000 Tons Removed from the List of War-ships being Maintained.

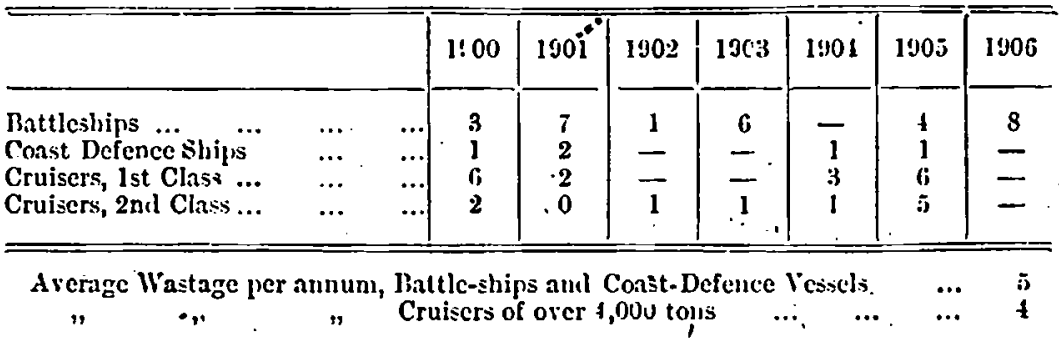

In the 14 years ending 1902 wo built at the rate of 3 battleships and 7 cruisers per annum. Taking armoured cruisers only, in six years ending 1902 inclusive we laid down an average of 3$\}$ battleships and $4 \frac{2}{3}$ cruisers, or 8 armoured vessels a year. Last year's programme was for 1 battle-ship and 3 cruiser-battle-ships, this year for 3 battle-ships, and ifext year for 2 or possibly 3 armoured vesscls.

$$
\text { N.-Tine Naval Annual. }
$$

Declucting the "Montagu," the Naval Annual gives the strength in first-class battle-ships as follows:-

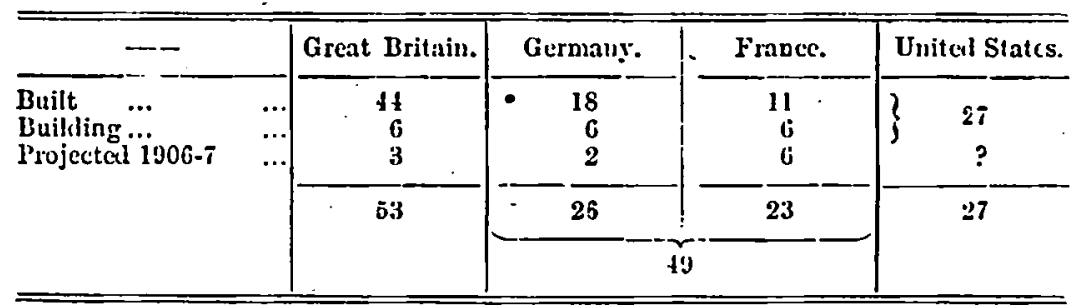

$$
\text { United States and Germany }=53 \text {. }
$$

Ten per cent. margin over next two Powers requires 58 battleships for Great Britain; actual number, 54. The United States Navy Department propose to increase the original programme of 1906 by two battleships, in which case the two-Power standard requires us to have under Naval Annual classification 61 battle-ships instead of 53 . 


\section{O.-Estiante frodi "Figiting Ships." \\ (Includes Cruisers.)}

\begin{tabular}{|c|c|c|c|c|c|c|}
\hline \multicolumn{3}{|c|}{ Mate. } & Great Iritain. & $\begin{array}{c}\text { Unitel States } \\
+ \\
\text { France. }\end{array}$ & $\underset{\text { Cicrmany. }}{+}$ & $\begin{array}{c}\text { France } \\
+ \\
\text { Germany. }\end{array}$ \\
\hline $\begin{array}{c}\text { I. } \\
\text { I. II. } \\
\text { III. } \\
\text { III. } \\
\text { II. } \\
\text { V.TIS. } \\
\text { VII. III. } \\
\text { VIII. }\end{array}$ & $\begin{array}{l}\ldots \\
. . \\
\ldots . \\
\ldots \\
\ldots \\
\cdots \\
\ldots \\
\ldots \\
\cdots \\
\ldots\end{array}$ & $\begin{array}{c}\cdots \\
\cdots \\
\cdots \\
\cdots \\
\cdots \\
\cdots \\
\cdots \\
\cdots\end{array}$ & 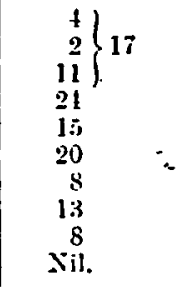 & $\begin{array}{r}3 \\
6 \\
19 \\
1 \\
13 \\
19 \\
15 \\
17 \\
5 \\
3\end{array}$ & $\left\{\begin{array}{r}3 \\
2 \\
13 \\
19 \\
3 \\
25 \\
5 \\
10 \\
2 \\
1 ! \\
1 !\end{array}\right.$ & $\begin{array}{r}r i 1 . \\
8 \\
6 \\
14 \\
10 \\
20 \\
15 \\
17 \\
6 \\
16\end{array}$ \\
\hline
\end{tabular}

The remaining vessels folong to the "Blake" period, and protected cruisers or obsolete vessels.

\section{P.-Tue Naval Pocket Book.}

Great Britain's position relative to that of any two Powers :-

Battc-slips launched in or since 1895 of 12,000 tons or upwards $\ldots$.. $\quad . \quad+6$ Pattlc-ships orer $\mathrm{S}, 000$ and under 12,000 tons launched since $1887 \quad \ldots \quad \ldots \quad$ -

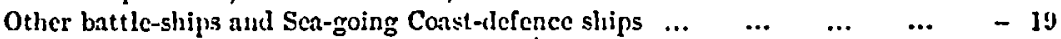

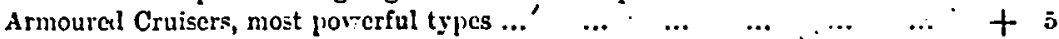

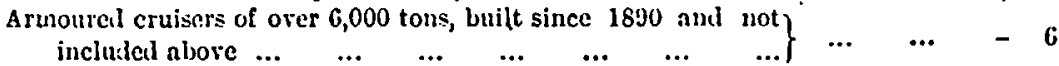

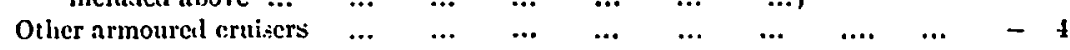

The above in no case gives the requisite margin laid down by the Admiralty as a minimum.

Q.-Battle-Ship Strength according to the "Royal Navy List," Остовеп, 1906.:

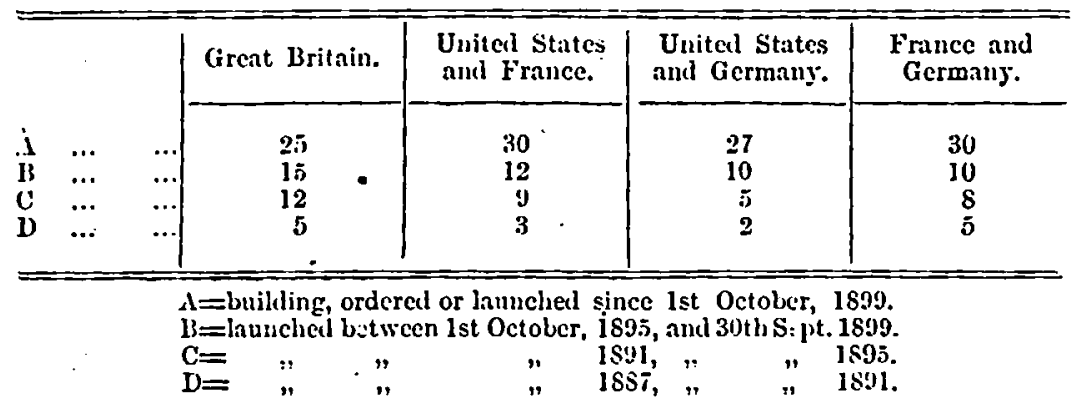

\section{R.-Navy League's Comparisons.}

Under a Common System of l'oints and Classing Effective Ships.

Summary of force in battle-ships and armoured cruisers, including ships to be laid down in $1907:-$ 


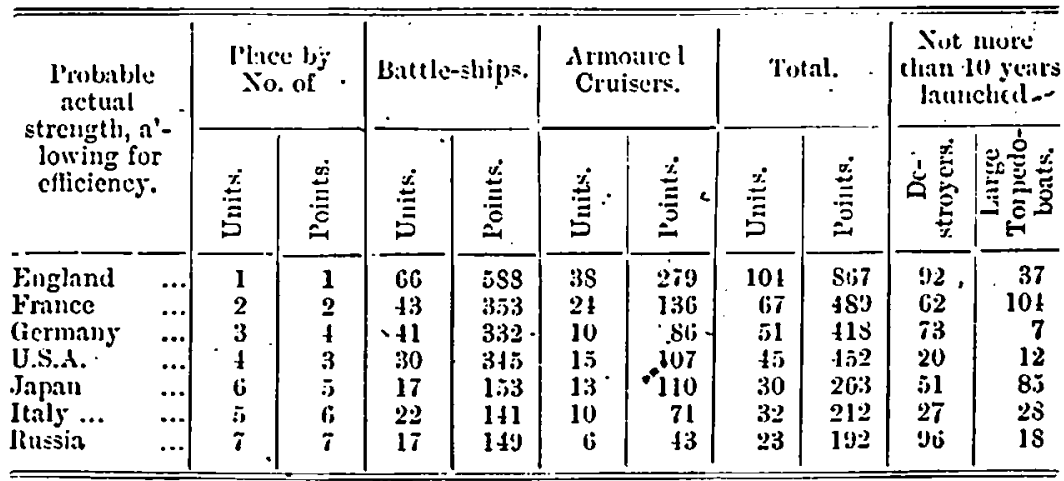

Summary of force in effective battle-ships, armourcd cruisers, and modern destroyers, including ships to be laid down in calendar year, 1907 :-

\begin{tabular}{|c|c|c|c|c|c|c|c|c|c|c|c|}
\hline & & \multicolumn{2}{|c|}{$\begin{array}{l}\text { Plice by } \\
\text { No. of }\end{array}$} & \multicolumn{2}{|c|}{$\begin{array}{l}\text { Fffectire } \\
\text { Battle-ships. }\end{array}$} & \multicolumn{2}{|c|}{$\begin{array}{l}\text { Armoured } \\
\text { Cru.isers. }\end{array}$} & \multicolumn{2}{|c|}{ Tutal. } & \multicolumn{2}{|c|}{$\begin{array}{l}\text { Not more } \\
\text { thian } 10 \text { years } \\
\text { launched. }\end{array}$} \\
\hline & & . & $\stackrel{\mathscr{E}}{\stackrel{E}{E}}$ & 范 & 葛 & . & 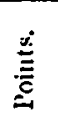 & $\stackrel{\dot{\Xi}}{\leftrightarrows}$ & 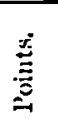 & 苞蜜 & 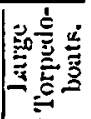 \\
\hline $\begin{array}{l}\text { Germany } \\
\text { Japan } \\
\text { Italy ... } \\
\text { Russia }\end{array}$ & $\begin{array}{l}\cdots . \\
\ldots . \\
\ldots . \\
\ldots . \\
\ldots . \\
\ldots\end{array}$ & $\begin{array}{l}1 \\
3 \\
2 \\
4 \\
5 \\
6 \\
7\end{array}$ & $\begin{array}{r}1 \\
2 \\
3 \\
3 \\
4 \\
5 \\
6 \\
\frac{6}{7}\end{array}$ & $\begin{array}{r}14 \\
25 \\
23 \\
24 \\
12 \\
9 \\
8\end{array}$ & $\begin{array}{r}475 \\
302 \\
27 \pm \\
257 \\
-133 \\
101 \\
112\end{array}$ & $\begin{array}{l}35 \\
10 \\
21 \\
10 \\
13 \\
10 \\
6\end{array}$ & $\begin{array}{r}272 \\
107 \\
127 \\
86 \\
110 \\
70 \\
43\end{array}$ & $\begin{array}{l}82 \\
40 \\
47 \\
31 \\
25 \\
19 \\
14\end{array}$ & $\begin{array}{l}747 \\
409 \\
401 \\
343 \\
244 \\
171 \\
156\end{array}$ & $\begin{array}{l}92 \\
20 \\
62 \\
73 \\
51 \\
27 \\
90\end{array}$ & $\begin{array}{r}37 \\
12 \\
\vdots \vdots 101 \\
. .7 \\
\vdots 55 \\
23 \\
23 \\
19\end{array}$ \\
\hline
\end{tabular}

\section{S.-Tife Return of Fleets (Great Britain and Foreign Countries).}

"I ain desirous that the Return should give an accurate, complete, and faith" 1 l picture of the strength of the Navy."-Mr. Edmund Robertson, 8th November, 1906. ment.

This Return is the only official information granted to Parlia.

It claims in the explanatory notes to include only vessels in " the official effective fighting strength of each Navy." Of the numerical statement of vessels arranged in classes, the explanatory notes say that it "shows in a convenient form the comparative strengths of the various Powers."

The bonat-files of the Admiralty in this matter can be tested by the following criticisms :-

1. The 86 protected cruisers given in the list include " $\Lambda$ pollo," "Intrepicl," "Spartan," "Retribution," "Rainbow," "Tribune," "Naiad," "Melampus," "Andromache," "Pique," "Pomone," "Pactolus," "Philomel," "NLedea," and "NIedusa." None of these vessels, except the "Philomel," have had any money spent on them for maintenance since October, 1904. Their names were long ago 
- removed from the list of effective ships given on page $270 e$ of the "Nav́y List," and they all appear on page 405 of the "Navy List,". of vessels available for subsidiary services, hulks, and vessels for sale. The "Philomel" had over $£ 23,000$ spent ou her in 1903-4. She was under the Redist,ribution Scheme of October, 1904, put on one side without maintenance. In 1906. it was decided to refit her for some subsidiary purpose, but it was found at Haulbowline that such was the deterioration of two years that an extensive refit was again necessary.

2. As regards battle-ships, there are twelve included in the retura on which no money.. las been spent for maintenance. The names of these battleships are: "Sans Pareil," "Anson," "Canperdown," "Benbow," "Howe," and "Rodncy," included as firstclass battle-ships; "Colossus," "Edinburgh," "Thunderer," and "Devastation," included as second-class battle-slips; and "Hero" and "Couqueror" as third-class battle-ships. It is officially stated that less than $£ 1,500$ has been spent on the six so-called first-class battle-ships during the last 18 months, and that this sum was not spent with a view of maintaining them, but with the view of preventing any extensive deterioration in tlieir sale value.

3. On 13th June, the Financial Secretary to the Admiralty explained that these battle-s'lips "are on tho verge of becoming obsolete, and it is, therefore, a matter of choice whether or not they should be included in a list which is meant for general information, and does not profess to contain any detailed classification. It has been considered, on the whole, preferable that they should be included for the present until they are finally removed from the list of the Navy." The quotations I have given from the explanatory notes of the Return show this statement to be inaccuratc. I think I have also shown how misleading was Lord Tweedmouth's assertion in the House of Lords, 30th July, that " Every man from that Return can judge for himself what the relative strengths of the British flect and otler flects now arc."

\section{T.-Geriman INcrease.}

The programmes of the German Navy, sanctioned under the Navy Bill of 1906, are given in the following table:-

\begin{tabular}{|c|c|c|c|c|c|}
\hline lear. & B:attle-ship. & $\begin{array}{l}\text { Armoured } \\
\text { Cruisers. }\end{array}$ & $\underset{\text { Cruisers. }}{\text { Small }}$ & 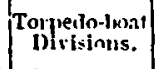 & Sum to lie spent. \\
\hline $\begin{array}{l}1906 \\
1907 \\
1905 \\
1909 \\
1910 \\
1911 \\
1912 \\
1913 \\
1914 \\
1910 \\
1916 \\
1917\end{array}$ & $\begin{array}{l}2 \\
2 \\
2 \\
2 \\
2 \\
1 \\
1 \\
1 \\
1 \\
1 \\
1 \\
2\end{array}$ & $\begin{array}{r}1 \\
1 \\
1 \\
1 \\
1 \\
2 \\
2 \\
1 \\
1 \\
1 \\
1 \\
1 \\
-\end{array}$ & $\begin{array}{l}2 \\
2 \\
2 \\
2 \\
2 \\
2 \\
2 \\
2 \\
2 \\
2 \\
2 \\
2\end{array}$ & $\begin{array}{l}2 \\
2 \\
2 \\
2 \\
2 \\
2 \\
2 \\
2 \\
2 \\
2 \\
2 \\
2\end{array}$ & $\begin{array}{r}\mathcal{E} 12.336,000 \\
13,496,000 \\
11,000,000 \\
15,03 n, 000 \\
15,423.000 \\
15,66 i, 000 \\
15.931,000 \\
16,024.000 \\
15,800.000 \\
15.835 .000 \\
15,087.000 \\
16,132,000\end{array}$ \\
\hline Totals... & Is & 13 & $2 t$ & $2 t$ & \\
\hline
\end{tabular}


As showing the increase over the Navy Bill of 1900 , it may be stated that the sum to be spent for 1906 under the Bill of 1900 was $\$ 9,877,500$, whereas $£ 12,336,000$ is to be spent.

The following table, from the report of the Treasury Committee of 1859 , on the state of the Navy, shows how we maintained our position against our chief rival in the past. $\Lambda$ programme of threc ships a year cannot possibly keep up such a standard agninst Germany in the future:-

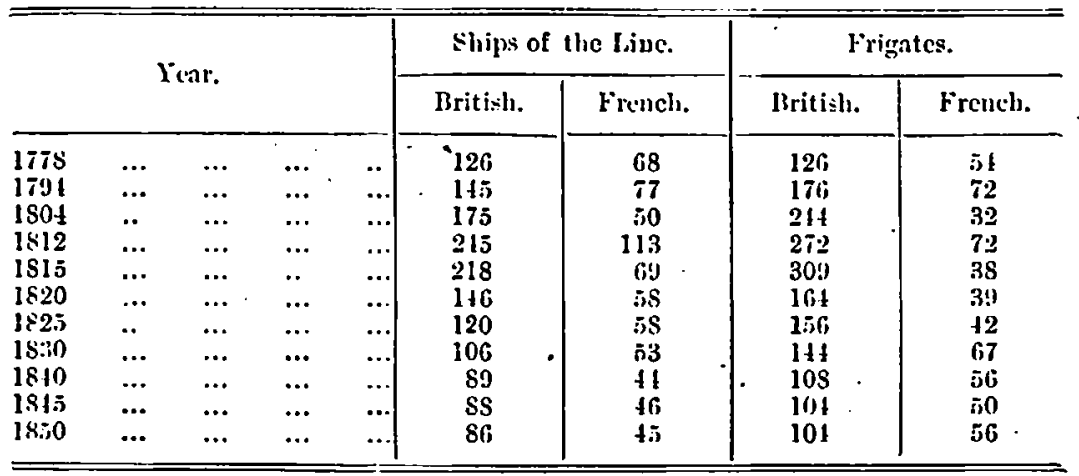

\section{U.-Prince Buelow's Standand.}

In view of Prince Buelow's declaration that the Powers require navies in proportion to their maritime interests, and that "the German Navy is still very small in proportion to her oversea commercejudging their relative dimensions by those of other nations," the following figures are included:-

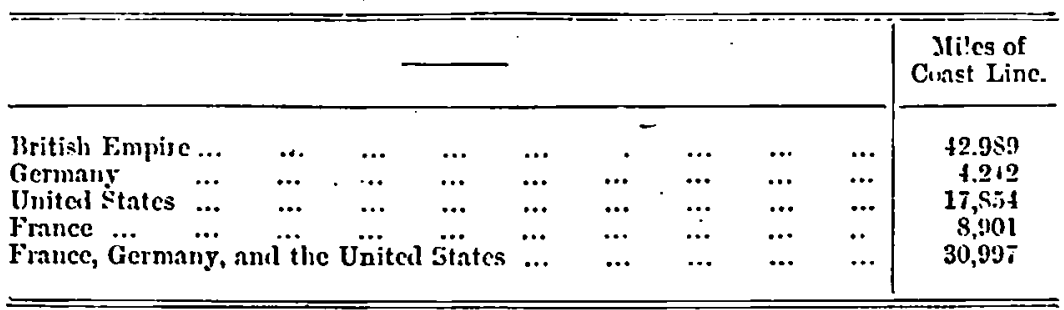

\begin{tabular}{|c|c|c|c|}
\hline & British Empirc & Germany. & $\begin{array}{l}\text { Standard proportion } \\
\text { British to German. }\end{array}$ \\
\hline $\begin{array}{l}\text { Stam tonnage in gross tons } \\
\text { (10().-t;. I lordis legister) }\end{array}$ & $\begin{array}{c}\text { Tons. } \\
15,410,000\end{array}$ & $\begin{array}{l}\text { T'ons: } \\
3,09+, 000\end{array}$ & 5 to 1 \\
\hline $\begin{array}{l}\text { Annual Clearances in Foreign } \\
\text { traule in tons }(1901)\end{array}$ & $79,2: 0,000$ & $16,319,000$ & 5 to 1 \\
\hline $\begin{array}{ccc}\text { Va'ue of direct trade by eca } \\
\text { in } 1901 \\
\ldots\end{array}$ & $£ 1, f 62,000,000$ & $f .260,000,000$ & 51 to 1 \\
\hline
\end{tabular}

In addition it should be stated that while German Colonies are unimportant, so that the Empire may be said to be concentrated in Europe, and united by land roads, only $1 * 1$ per cent. of the British 
Empire is in Europe, and it is united to the remainder by sea roads, viz., 34.4 per cent. in America; 25.8 per cent. in $A$ ustralasia: 21.5 per cent. in Africa; and 17.2 per cent. in $\Lambda$ sia.

\section{V.-Cruisens.}

Extracted from the debate, the House of Lords, 21st March, 1905 :-

Lord Spencer.- "I have always maintained that we must have a much larger number of cruisers than any two other Powers."

Lord Selborne.-." The duties of cruisers are two-fold. They have to act as the eyes and cars of the battle-fleet, and also to protect our trade. Now, I can only say that in that respect I am more anxious on the subject of cruisers than I am on the subject of battleships. . - I do not think we have any too many fast armoured cruisers, and I should be very sorry if any succeeding Board of Admiralty in any way slackened off in their supply to the Navy of those ships."

The only comment to be made on these speeches is, that we have given up building cruisers altogether, and it is even claimed that the three "Invincibles" of last year's programme, voted as cruisers, are in reality battle-ships.

The memorandum on Admiralty Policy, 30th November, 1905, page 24, stated that, in the opinion of the Board, the best of the unarmoured cruisers which had been retained for the present must be allowed to die out within a few years; or, in other words, 86 cruisers in the Return of Flects, or 71 mentioned in the Navy List, must vanish in a few years, leaving 35 armoured cruisers and 3 "Invincibles" to do their duties. There are in addition 8 "Scouts" of limited coal endurance.

An earlier opinion of the Board was given in the Admiralty memorandum, 6th December, 1904, on the redistribution of the Fleets. Where dealing with the armoured cruisers it is written:-

"With such ships even the best so-called 'protected' cruisers would engage at a considerable disadvantage, and the slower or smaller 'protected' cruisers would be hopolessly outmatched; their only hope of safety would be in niglit, and they could not flee because they have not the necessary speed."

This criticism, while covering the case of nearly all our protected cruisers, is scarcely a satisfactory explanation as to how the Admiralty propose to provide all our fleets with scouts and look-outs from $3 \overline{5}$ armoured cruisers and 3 "Invincibles," and yet arrange for chasing down 24-knot protected cruisers, such as Germany is building at the rate of two a year. (See Appendix T.)

Obviously these vessels are intended, if conditions are favourable, to attack our commerce. The natural answer is to build more cruisers; but this is precisely what we are not doing. We had the "Invincibles" under last year's programme, but to use "Invincibles" to search for little commerce destroyers is an enormous waste of force. This year no cruisers are to be laid down, next year a mother ship for destroyers, but still no cruisers, and the year after, in the endeavour to keep the Navy Estimates from rising, as the "savings" have 
already been pledged, the Admiralty will be torn between the connicting needs of battle-ships, cruisers, and destroyers.

I doubt if the Chambers of Commerce realise that the plain meaning of the Admiralty statement is, that by the time we can build a cruiser, starting from next jear's programme, we shall have only $3 \overline{5}$ cruisers and 3 "Invincibles." Tone the Admiralty's statement down as we may, its gravity cau hardly be exaggerated when compared with the opinions of high authorities as to our requirements, e.g.:-

a. The Prize Essayist in 1903 said that apart from the defence of commerce, we required 74 cruisers for scouting and look-out duties with the fleets in a war with two Powers.

d. Admiral Sir Cyprian Bridge told the Food Supply Commission that apart from our scouts and look-outs, we required a numerical advantage of 50 per cent. as compared with the hostile cruisers attacking commerce.

Clearly if one cruiser escapes we must send at least two after her, or a margin of 100 por cent. If two cruisers escape, three will be required, or a margin of 50 per cent., and so forth. So foreigners will decline to play our game, and will act in small detachments.

This is the true inwardness of Germany building 24-knot cruisers at the rate of two a year. At the same time she reaps the full advantage of the turbines, which add about two knots to the speod.

It cannot be pretended that even for peace duties we can manage without a large supply. The refit of the "Philomel" is a case in point. This vessel had $£ 23,000$ spent on her in 1904. She was set aside as valueless the same year. Having deteriorated for two years, she is again towed round to Haulbowline to be refitted at great cost for peace service. Consequently the policy of 1904, of employing only ships fit for fighting, is breaking down for lack of fighting ships.

In consequence of the Russo-Japanese war, where both nations neglected all considerations of commerce defence, a practice has arisen of reckoning armoured cruisers as available for the line of battle. Foreign navies, prepared to sacrifice their commerce, no doubt will be able to use their cruiscrs to assist the line of battle, if in any way fit for the purpose, or in the alternative, divert them to the attack of lines of communication, even as the Boers forced on us inordinate preparations by sometimes appearing as guerillas and sometimes as an army.

\section{W.-Destroyens.}

The life of a destroyer is a very short one, and it is in view of this fact that the following table furnished by the Admiralty is alarming. It should be clearly understood that Germany will for some years to come lay down 12 additional destroyers per annum. The Admiralty state that the number of destroyers laid down since 1899 , inclusive of those laid down under this year's programme, is as follows :-

$\begin{array}{llllllll}\text { Great Britain } & \ldots & \ldots & \ldots & \ldots & \ldots & 44 \\ \text { France } & \ldots & \ldots & \ldots & \ldots & \ldots & \ldots & \mathbf{5 3} \\ \text { Germany } & \ldots & \ldots & \ldots & \ldots & \ldots & \ldots & \mathbf{4 8}\end{array}$


The Germans reckon only ten years as the life of a destroyer. in our published official lists of destroyers we inclucle among our own all the old vessels, 58 of them over ten years old, while a large number will reach that limit shertly. W'c maintain 36 destroyers in full commission, and 21 of these are at Portsmouth and Plymouth. On the other liand, the Germans have 33 in full commission at Wilhelmshaven.

As with our ships, so with our destroyers; they will have to keep. the sea, and must spend one day in harbour, coaling, etc., for every. two at sea. It follows that to secure equality on the fielid of operations against an enemy waiting for his opportunities, we mnst have a supcriority of one-third.

In addition, Great Britain has laid down 24 of the large torpedoboats known. as "coastal destroyers." Clearly, to class them with modern destroyers, costing 3 to 7 times as much, is inadmissible. Even former types of destroyers of less nominal speed, such is the "River" class, cost twice as much as the new coastals.

The mission of the destroyers at Port Arthur was to get in the first blow. It is stated that we are to have in the Mediterranean only 18 destroyers. The question must be asked: What can 18 destroyers hope to achicve in regard to the half-dozen French torpedo bases? Taking all sorts of first-class torpedo-boats as above, France and Germany have 516 torpedo craft and 91 submarines to our 248 torpedo craft and 40 submarines. These are threats to the battle. ships necessitating, as I lave pointed out in my paper, a margin of safety against possible successes.

\section{X.-British Expenditune on New Silips, for 20 Yenrs.}

For 20 years past our average expenditure on new construction has been $f 6,509,000$ per annum, but at the beginning of this period the cruisers we built were of the "Mersey "type, or one eleventh of the cost of the "Invincible," while the battle-ships of to-day are $2 \frac{1}{2}$ times as expensive as the "Admiral" class of that day. So the average for the ten years ending 1906 has, risen to $£ 8,370,000$. At the beginning of this ten-year period battle-ships cost half what they do now. In addition, in 1886 we only considered France; by 1896 Russia had appeared on the scene; and by 1906 we have Germany, the United States, and Japan as well. The official estinate of the value of the Navy, alloning for depreciation, is $£ 127,000,000$. Thus an annual expenditure of $\overline{5} \frac{1}{2}$ millions sterling would do for replacement, but for the rise in the cost of vessels. For the 15 years ending 1884, new construction formed about one-seventh of our total Navy vote. With compound armour the amount jumped up to about one-fifth. In 1888.9 the ordnance vote was transferred to the Navy. Allowing for this transfer, new construction now forms from one-fourth to one-thind of the remainder.

\section{Y.-Relative Shipbuilding Expenditure.}

A frequent error made in comparing the new construction expenditure of the Powers is that no regard is paid to the concealed expenditure under other votes. Thus, gun mountings, which are so lieavy an item of expenditure in ships, appear under new construction in Great Britain, but not so in France and Germany. The copy 
of Lord Brassey's pamphlet sent to me gives the new construction. vote of France and Germany as $£ 6,731,610$ (p. 8). The figure for Great Britain, including gun mountings, in 1906 is $£ 9,252,000$; but the only one mentioned in the copy of the pamphlet is the swollen figure of 1904 .( $£ 11,600,000)$, when we purchased the "Swiftsure" and "Triumph." The fallacy underlying these figures is one I have frequently diawn attention to. To get at the correct figures one must include the whole preparation of ships for war, viz., shipbuilding, repairs, and armaments.

Mr. W. H. Cowan, M.P., of the Liberal Navy Committee, on 14th November, obtained the exact corrective required by a question in the House of Commons.

Aggregate Sums Toted or Expended for Shipbuilding, Repairs, and Armaments.

Great Britain.

\begin{tabular}{|c|c|c|}
\hline & $\begin{array}{c}1901-2 . \\
\text { Actual Fxpenditure. }\end{array}$ & $\begin{array}{l}1 ! ! !(j-\overline{-} . . \\
\text { Fistimate. }\end{array}$ \\
\hline 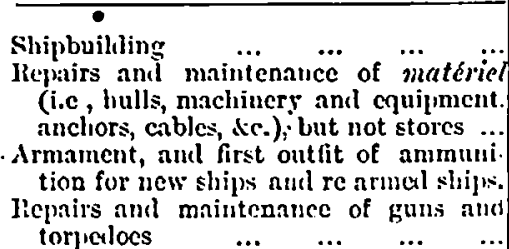 & $\begin{array}{r}8,86, j, 0 \leq 0 \\
1, \pi i 1,420 \\
1, \pi 16,600 \\
133,960\end{array}$ & 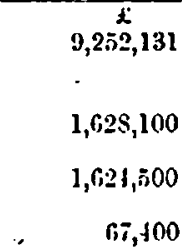 \\
\hline Total & $12,317,000$ & $12,372.131$ \\
\hline
\end{tabular}

France and Germany.

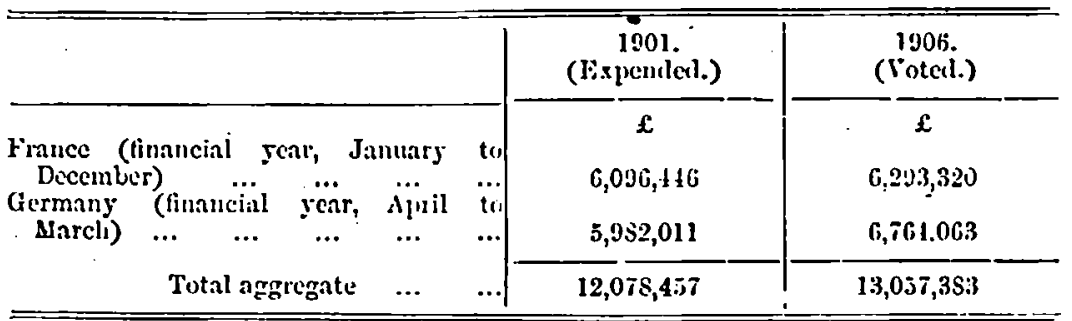

From the above it is clearly seen that whercas formerly our expenditure exceeded that of France and Germany, it is now inferior. Yet ten days after this positive proof is obtained by the Liberal Navy Committee, The Speaker, in its issue of 24 th November, prints the following grossly misleading statement:- "In the shipbuilding votes for the current year the British Parliament has made provision far exceeding the two-Power standard." I venture to forecast from a careful study of existing programmes that our expenditure in connection with the preparation of the war materiel of the fleets will be 31 millions sterling less than the combined expenditure of France and Germany next year. 


\section{Z.-Relative British and Foreign Expenditure.}

Sir Edward Grey at the Eighty Club on 31st May, 1905:-

"The present Army and Navy listimates apparently have no relation whatever to the policy of Inperial defence which he (Mr. Balfour) has laid down. The policy points to the reduction of the Army istimates and considerable expenditure on the Nary; and we understood that the present Government intended to reduco the Army Estimates, but that it wonld certainly spare nothing to maintain a strong Nary. Well, it has done just the opposite; it has increased tho $\mathrm{Army}$ Estimates and reduced tho Navy listimates. Now, I agree that in much of the changes in the Government there appears to bo what makes both for cconomy and efficiency; but I confess I am a littlo alarmed by statements wifheh I have seen, with regard to our reserve of naval guns. I wish before the Government began applying their doctrines of economy to the Nary they had ap. plied those doctrines to the Army, where I believe thero is a much larger and inuch safer field for economy."

I have seen several comparisons of expenditure lately which convey erroneous conclusions. The writers forget-as reference books omit to mention as well-that the German Estimates do not include pensions, that the French Estimates underwent a fictitious decrease in 1902 and subsequent years, involving about a million sterling, through the transfer of the Marines to the War Department. The Admiralty figures, allowing for pensions, show that the relative increase for the last two years of the German Estimates in comparison with our own is $£ 7,086,000$. What will be the position next year? Both our own and the German Estimates are pledged in advance, the Germans to increase $£ 1,160,000$, and ours to decrease by what I estimate to be $£ 1,800,000$. This gives a relative German increase for the three years ending 31st March, 1908, of $£ 10,000,000$ sterling. If our Estimates after that remain stationary, the German Estimates sanctioned for 1909 provide for a further increase of $£ 1,534,000$. Wo have thus the liuge relative increase of $11 \frac{1}{2}$ millions sterling.

The only point that can possibly be in dispute is my estimate as to our own decrease next year. It is founded on Mr. Robertson's speech on 27th July. Mr. Robertson then said:-

"I do not think that the full financial effect of our proposals will be felt till next year. The financial effect on next year's Estimates (1907-8) will be that there will be a lightening of those Estimates to the following extent:-

"Vote 8 , by the sum of $£ 1,305,308$.

"Vote 9 , by the sum of $£ 1,488,680$.

$$
\text { “Total, £2,793,988." }
$$

These reductions, he explained, were on what would have been the case if the full 1906-7 programme had been persisted in. A mother ship for destroyers (Lord Tweedmouth said a "scout") was to be laid down in June, but "the amount to be taken for new vessels in 1907.8 was to be limited to a small sum" in order "to emphasise to the Hague Conference the good faith of the British Government in its desire to bring about a reduction of armaments." Since the example was set on 27 th July, the German, Japanese, and American 
programmes have been increased by fresh demands, the South. American Republics have begun to order war-ships again, and the naval budget of every important Power, except our own, has gone up. As less than half-a-million is being taken for the new construction of this year, the emphasis on a sinall sum can only mean that about a quarter of a million at the outside is to be taken..

Mrr. Robertșon also said: "I do not want the Committee to come to the conclusion that what I have said exhausts the list of possible cconomies." This obviously refers to the saving through ceasing to effect repairs on 16 armoured ships which have hitherto been maintained with nucleus crews, and the placing of 11 armoured ships out of full commission. I have, therefore, given a conservative estimate, allowing a large margin for contingeficies, when I put the decrease at $£ 1,800,000$. Such contingencies iuclude the automatic rise of expenditure, once referred to by Mr. Robertson as $£ 665,000$, the new dock at Portsmouth, and possible expenditure on Rosyth.

I have compared our naval expenditure with the German, but that is not the whole story as in the view of the Cabinet part of the naval expenditure in this country is to balance the huge military strength of gunnery. - Thus Mr. Haldane said at Brighton this month:- "The expenditure on our Navy might be set against the " expenditure of those foreign Powers who laid out their, resources in taking two years of the best periods of the lives of their young men for compulsory service. The Statesmen of this country, who advocated compulsion, would be calling on the nation to pay twice over for the same thing."

\section{OPINIONS AS TO THE MEANING OF THE TWO-POWER STANDARD.}

"Beyond comparison with any two Powers."-Report of the Three Adnirals, 1888.

In his speech introducing the Naval Defence Act, 1889, Lord George Hamilton said :-

"The paramount idea underlying the utterances of those who in previous years have held my position and that of Prime Minister . . . has been that our establishment should be on such a scale that it should at least be equal to the naval strength of any two otlier countries. (Hear, hear.) . . . No amount of foresight or calculation can auticipate naval combinations and naval movements. For the purpose of meeting such unexpected blows we should have'a considerable margin of reserve." said :-

Sir Edward Grey in the House of Commons, 1st March, 1904,

"In 1885 the standard set and maintained by Mr. Gladstone's Government was to lay down two ships for every one ship laid down by the French Government. Under the Naval Defence Act, the standard changed. and there came the two-Power standard. That standard must not be taken to apply to any two Powers in particular, but to tho two Powers which at the time of spcaking had the largest Navies." 
Lord Selborne in the House of Lords, 21st March, 1905, said :-

"The two.Power standard never had applied to any two particular nations, but always to the two strongest naval Powers. - . If you compare the margin of security which Parliament provided under the Naval Defence $A$ ct of 1889 with the margin of security we at present enjoy, the margin was greater then than now."

Lord Cawdor on 3rd November, 1906, said :-

"The test the Admiralty applied to naval efficiency and the standari: they had set up for ycars pást as that which must be maintained was that we must be strong enough in battle-ships alone to defeat any combination of any two Powers, and that we should have a margin over and above this for contingencies of some ten ner cent. This was the minimum which they had considered safe. With respect to cur cruiser power, we needed and must maintain far more."

Extract from the Parliamentary debates, 31st July:-

MIr. Bellairs asked the Prime Minister whether he had communicated to the Admiralty his view that the standard of France and Germany was a preposterous one?

Sir II. Campbell-Bannerman:-“"I think they are quite aware of my views."

Tue House of Cosmons,

13th November, 1906.

Viscount Turnour:-To ask whether it was the settled policy of the Admiralty in framing their shipbuilding programme to meet ouly those programmes of foreigu Powers which were actually sanctioned by their respective Parliaments.

Mr. Robertson :-The answer is in the affirmative. The Admiralty were also guided by the number of vessels actually laid down, and the progress made in their construction.

(On 27th July, it should bs noted, Mr. Robertson made the announcement that the programme for the following year, 1907-8, would be cut down to two armoured ships to be laid down at the end of the financial year or March, 1908. If the Hague Conference failed to realise the Government's hope, three a:moured ships would be laid down.)

\section{The House of Londs, 30th July, 1906.}

Lord Tweedmouth:-It " was wiso and right to reduce the programme as it stood when the noble Earl left office. It was pro- posed, as the noble Earl said, to build four armoured ships. The outlook then was that France was going to lay down several very large battle-ships; the United States were going to lay down $(w 0$ new great battle-ships, besides two that had before been carried; Russia was going to lay down one first-class battle-ship and two armoured cruisers; and Germany was going to lay down two very large buttleships and one armoured cruiser. It uas in view of this knouledge that the programme uas originally framed.

The late Civil Lord of the Admiralty has denied that theso programmes were taken into consideration when our own was framed in November, 1905. The French and German programmes were only sanctioned in the spring. of this year. 
It is worth while to note in connection with the above statements how the naval policy of Great Britain fluctuates. In 1889, under the Unionists, we had the. Naval Defence $\Lambda$ ct, in which the money was provided at once for a programme over a period of five ycars. - In 1891, under the Liberals, we had a programme for five.years, the money being provided year by year. "The new scheme of construction," said Lord Spencer in his statement explanatory of the Navy Estimates in 1904, "forms part of a complete programme which has been arranged for a term of five years." The Secretary to the Admiralty explained that "the cost of the prugramme behind is very much larger," and "will involve for the five years ensuing a very liberal provision by Parliament of public money to meet the needs of the Navy." At Sheffield, 19th October, Lord Twcedmouth, forgetting that Mr. Robertson had given away next year's programme in advance, said: "The Admiralty believed that the best course wns year by year to form the programme of the year for the necessitics of the year estimated according to the exact amount of work which had been carricd out by our foreign rivals."

American Policy :-

"I would rather see the country abandon the Monroe Doctrine and give up all thought of building the Panama Canal than to see it attempt to maintain the one and construct the other while refusing to provide the means which can alone render its attitude as a vation worthy of the respect of nations and of maukind. There is one thing we must not do; and that is to bluff. Therefore, gentlemen, keep r.n building up and maintaining at the highest point. of efficiency the United States Navy or quit trying to be a big nation."-President Roosevelt, 22nd June, 1005.

\section{German Policy :-}

"Germany must have a fleet of such strength that a war, even against the mightiest naval Power, would involve risks threatening the supremacy of that Power."-Preamble of the German Naty Bill of 1900.

Adniral Tho Hoin. Sir lidsuld R. Fresastre, G.C.B., C.M.G. (RearAdmiral of the United Fingdom):-I have not had the opportunity of reading the paper or the valuable appendices to which the lecturer has referied, but at all events we have in our hands one valuable appendix, namely, the disgram shoring the rant of continuity in the British shipbuilding policy. I am rery glad the lecturer mentioned something about the Blue-Water School, because it is universally misunderstood. 'The late Admiral Colomb was the first to state what our policy ought to be, and the idea, generally speaking, is that we do not want so many defences round the coast, but that ne want a mobile Army. He always laid stress on tho necessity of that, and those who read it in a different way and talk about " no necessity for defence school," or something of that sort, wilfully misunderstand it, and wish to give it a bad name. The idea of the Blue-Water School is, that we want a rery good Army, but we do not want to overdo the defences, whether on the coast or in the interior. I feel inclined to mention some particular defences with which I an acquainted, which, I think, are distinctly in point. When I was in command at Plymouth I went on more than one occasion with I.ord Wolseles, 
who was then Commander-in-Chief, and Sir.Redvers Buller, then Adjutant- . General, to look at all the defences, including tholhigh-angle firing batteries, . which at that timo were much in farour. Thio object of the high-anglo fring batteries was to prevent a flect lying in Whitsand or Cawsand Bays and shelling the dockyard and ships in the harbour over the Maker Heights. I do not rant to digress en that point, only it occurs to me, as it must occur to overybody who has studied the question of the position of theso islands, that no enemy would ever dream of doing that unless wo were fighting an enemy which was in the position this country was in during the Crimean war, that is, having a very big Nary and a very small Army. Lieutenant Bellairs has mentioned the expenso of ner coustructions in this and other countrics, and I do not presume to follow him entirely there because I have not tho figures before me. I did, however, take the trouble to controvert eomo figures which were giren by Lord Brassey to the Chambers of Commerce Defenco Committec. The figures of Lord Brassey were, of course, perfectly and strictly accurate, but were entirely misleading, because he gave the figures for this year, and at tho samo time gave the figures for France and Germany for this year; but he knew perfectly well that wo were reducing those figures for this jear, and intending to reduce them very largely next year, and the figures of France and Germany-certainly thase of Germany-aro bound to increase, according to the new Act of 1906 . Therefore, those figures were quito unreliable. I sar a statement in the paper to-day, I think, that tho United States proposes to increase its Navy Estimates by rather over threo millions in the course of next year, and probably a very large proportion of that a mount will go in shipbuilding. While on that question, I should liko to refer to a pamphlet which has gone tho rounds, which looks very much as if it emanated from tho Admiralty. I do not know whether it did or not, but at any rate, it expresses what looks very much liko tho Admiralty view. I dare say some of you have scen it. It is a shilling pamphlet, which is very mell got up, and is called "Tho Truth about the Navy." Lieutenant Bellairs reforred to tho decreaso which has been mado in tho voto for tho shipbuilding for the present sear and the decreaso in the shipbuilding programne. Tho greater part of tho economy duo to this will show its influenco next year and the year afterwards. That state of things has been acquicsced in by a great many of the papers, and somo endeavour has been mado to justify it by naval experts, who somehow o- other scem to think that anything which is done by tho Admiralty is satisfactory, and that we aro not to uso our own judgment on tho subject at all. But "lixcubitor" has a chapter in his pamphlet in which ho gives a very good account of the new German det of 1906 ; and in referring to 1905, when our programme of four ships a year was laid down by the old Board of Admiralty, he speaks of the German ships as comparatively useless, and, in comparison with British ships of contemporary date, as leing strikingly deficient in gun power. That is the position which our Board of Adniralty had to mect so far as Germany is concerned when Lord Cawdor's statement was made in Norember, 1905. They may have had some idea of what was likely to take place in 1906, becauso coming events cast their sliadoms before; but, at the samo time, they could scarcely have had prescienco enough to know exactly what the German Act of 1000 was going to be, and I do not think they knew at all what it was going to be. What does "Excubitor" say about the German Naval Act of 1906? He says : "The significance of tho new naxal proposals which have been adopted by tho German Reiclustag hare not. yet been realised in England. They are intended to render the German 
Navs, until recently a negligiblo quantity in Europe, a force second only in strength to the British fleet itself. The 1906 amendment of the Geiman Naval Act of 1004 is equivalent to a further addition to the German Navy o: eighteen battle-ships, besides six arinoured cruisers of maximum size, power and speed, and a number of torpedo craft over and above tho provision made in the seventecn Jears' programmo of 1000." If that statement is correct, if there is any truth in it at all, tho decision to reduce our shipbuilding policy in July this year is absolutely untenable on strategic grounds. Of course, on cconomical grounds, if we are to go on tho principle that mo only vote supplics for the present year, and that tho futuro must talio care of itself, and if we do not care as long as wo mako a littlo economy this year what extravaganco takes placo in futuro years, under those circumstances perhaps they may be justifiable, but not on any common-senso principle. I lay great stress on what the lecturer eridently wishes to bring home to us moro than anything else, namely, the want of continuity in the British shipbuilding policy. It doas scem to wo that a programme is as absolutely necessary as a routino on board a ship. Wo havo a routino. on board ship, although we depart from it sometimes; but a ship without a routine is a ship without a system-is a ship which is not conducted on any scientific principles at all; and it appears to me that that is very much the principle on which our shipbuilding polics is conducted. You must also remember that tho extravaganco of such a policy is vory great. Wo all know what the cxcuse for the reduction is. - What is it? Because neither France nor Germany has laid down a ship in tho present year. And why lave not they laid a ship down? Because they propose to mako very much greater strides in the future; because they intend to expend so much more, because they intend to rival us, and under thoso sircumstances they are obliged to hold their hands for a moment, becauso shoy are not ready to build thaso largo ships which wo haro set them the example of building. If our cont is to be cut so exactly to the cloth of other nations ( $I$ do not approve of that policy at all); but if that is "so, tho loss of tho "Montagiu" the other day ought to have been inmedintely made good. In my opinion that ought not to be our principle. Wo ought to have some continuity of policy; wo ought to have something like a programme, and some margin: This question is an-old hobby of mine. I recollect that I spoke to Lord Selborne about it once or twice, and ho said in reply : " The fact is, re have a programmo at the Admiralty, but we aro not going to tell everybody what it is."! If they haro a programmo at the Adiniralty, it is an extremely elastic ono, as the lecturer has shown. You can seo that, not only in regard to tho battle-ships, but in regard to the torpedo flotilla. There is only one moro thing to which I would like to allude, becauso I have detained you quito long enough already, and that is tho question of the tonnago argunient, which I think the lecturer has fairly disposed of. It is, of course, perfectly ridiculous to use that argument when wo take into consideration such ressels as those of the "Diadem" class, ressels of the "Terrible" class, and thoso very large vessels which pile up the tonnage, no doubt, but are really only nonuments of the mistakes we have made. I do not know what our friends the Japanese think about it, but they da not build ships with unarmoured ends. Captain Klado, in speaking of the loss of the Russian ships, attributed a great deal of it to the fact that they had unarmoured ends. Under those circumstances, as we have a greit number of ships with unarmoured cuds which liave been objected to by naval officers, I think tho sooner they are replaced the better. There is only

VoL. LI. 
one moro point to which $I$. will refer, and that is the pious opinion expressed by the lecturer, that wo shall always have a redundaney of men. I should very much like to know whether the Japaneso found that that was the case. Lieutenant Bellairs says, truly enongh, that unless the ship goes down very few stokers are lost; but a great many of tho Russian and Japanese ships did go down. We know that the Japanese themselves lost trio battle-ships besides several other ressels. But not only that, I should like to know how the wear and tear affected the health of the men. You cannot keep men at sea constantly engaged in warfare, and deprive them of the comforts which they obtain when they are not

- nt sea, and keep them in the best of health. I am quite certain that as regards the oflicers, the losses will be rery heary from the amount of responsibility they will-have to bcar. - I cannot help thinking, also, that it will be the same with the petty officers, if not with the men. I do not wish to detain you any longer; I only wish to say how very glad I an that the lecturer has brought this subject before. us. On the quastion of ship construction and the ships we ought to have under construction, there is no one who has given more attention to the subject, and no one more capable of giving an intelligent opinion upon it than Lieutcuant Carlyon Bellairs.

- Admiral Sir Natinasier Bownfa-Surir, K.C.B. :-I find it difficult to offer any northy remarks on the hon. gentleman's lecture, because the paper was only put into my hands as I entered the theatre, and I have not eren looked at the appendices. In the paper which Lieutenant Carlyon - beilairs kindly read to the members of this Institution in Jume, 1904, ho expressed a hope that the cost of a battle-ship might rise to $£ 2,000,000$, as in that case he ventured to think some of the foreign Powers would not - be able to continue in the competition. As regards the actual cost of a first-class battle-ship, it appears as if his wish would soon bo gratified, but this great cost does not scem to stop their construction. Tho Japaneso have recently launched one of 18,000 tons, and the German Reichstag, by their Naval Amendment Act of 1906, have authorised the construction of 18 such ships betreen the present time and 1917. But although I do not feel competent to criticise the paper, I should like to offer a few observations on the standard of naral strength, because certain newspapers and writers scem to be endeavouring to get up a naval scare. Now, whilst giving these gentlemen every credit for sincerity and patriotism, I do not find myself in agreement with them. After studying tables relating to these matters I maintain that with regard to European nations our tro-Porer standard is well maintained, and more than maintained. That being the case, I submit that it is a mistake to build ships in adrance of our requirements, because such rapid improvements tako placo that what mas be quito up-todate to-day mas be slightly behind the times in tho following ycar; and Sir William White, in one of his recent interesting letters to the Times, has pointed out that we can build ships, and carry out all the details of equipment, much more rapidly than other nations. Besides, wo havo reason to know that although the construction of certain foreign ressels is authorised, there does not seem at present to be any gresat hasto in laying them down. Sir Fdmund Fremantle has alluded to a pamplete, quite recently printed and distributed anonymously, on the question of the comparative strengtli of Navies, but I beg leare to ctate that I formed my opinion on this subject beforo I saw "The Truth alout tho Nary." That pamphlet, howerer, has confirmed my conrictions, and appears to have been written by someone well up in tho 
subject. As allusions have been made in some quarters to the present strength of tho German flect and the possibility of a sudden attack on us from the fact that nearly the whole of their naval power is concentrated in the North Sea, let us just consider the position. We will allow that the Germans have tro squadrons, eacl of 8 battle-ships, ready for service. There would be 8 ve'ssels of the "Deutschland" and "Braunschweig" cluss, of 13,200 tons, with 411 -inch guns each and smaller armament, and 8 vessels of the "Wettin" and "Kaiser Barbarossa" class, of 11,000 to 12,000 tojs, and their 4 9.1-inch guns cach and smaller guns.. Our present Channel Fleet is, I understand, to consist of 14 battle-ships, tho tw:o first of 16,500 tons, eight others of orer 16,000 tons, and two moro of 15,000 tons, the whole much more hearily armed than the German ships. Licutenant Carlyon Bellairs objects to this comparison by tomnage, but it is impossiblo in a few minutes to go into all details of armour and armament. Behind the Channel Fleet we have the Atlantic lilect of 6 modern, well-gumnel battle-ships, and as an immediate reserve we have the IIome Flect, manned with nucleus crews, and tho "Dreadnought," with a complete crew, as flig-ship. Our preponderance of cruisers is rery considerable also at present, but if the German nation carry out their iutention of constructing 18 battle-ships of "Dreadnought" dimcnsions (and I have not much faith in the coming Peace Conference), then we must go ahead with our building and keep well in adrance. The hon. lceturer contemplates a danger ahead in reducing our naval construction in any ono yea. because some Members of Parliament, and especially the Socialist Members, will look upon any reduction as permanent, and vill in future object to any necessary expenditure; but $I$ cannot think that a Gorernment like the present, backed up by the largest majority we lave ever known, will be deterred from doing their duty to the country by a small body of Members who call themselves Socialists. Is for the Labour Members generally, I believe they are far too patriotic and levelhesded to allow the risk of their country getting under tho heel of any foreign Porrer. In the construction of new vessels in pence timo I should not encourage overtime in order to obtain rapid completion. Doubtless there aro men who are glad to earn higher daily wages, but tho usual hours are sufficient for their health and well-being; besides which, three men morking orertimo may prevent a fourth from working at all, which is bad for him, and still worse. for his wifo aind children. In times of execrgency nien must, of course, be called upon for every effort, when we may, I fell convinced, rely on their co-operation.

Mr. L. Cope Conxrond:-I feel great diffidence in speaking after tho distinguished officer who has just given us his riews on what he calls a naval scare. I am delighted to hear the Admiral say there is no necessity for a naval scare, because on the facts which havo been adduced by the lecturer, and other facts to which he referred incidentalls, I perocnally was of an entirely different impression. If you will allow me a fer moments I will put a few considerations before you. With regard to the question of shipbuilding, tho lecturer has said very clearls all that is necessary, so that I need not touch on that point at all. With regard to the personnel, Licutenant Bellairs assumes that wo have quite sufficient personncl in time of war; but there are other things to be considered, and among them is the condition of the personincl at this moment. I rould like to point out to this meeting that $30,000 \mathrm{men}$ and more aro kept in brrracks ashore, instend of being under training at sea, and that the reduction of the sea-going squadrons by six battlo-ships and four cruisers 
will place another 8,000 or 10,000 men on halt training. Nithough tho Admiralty Memorandum of 24 th October states that those men will bo afloat and not ashore, it means that they will live on ships in harbourexactly as tho Russians did in their ships at Port Arthur, and exactly as the Russians do in tho Baltic. Flect in the sumner, while they live ashoro in the winter. That is not a reassuring proposition. I should also like to pcint out, as tho lecturer has told you, that cight battle-ships of tho "Rojal Sorereign" class are stated to have been placed in the special reserve mith skeleton crems. We have also been told in the Houso of Commons that five ressels of tho "Admiral" class, and the "Sans Pareil" and other obsolete resels aro to be sold. The " Renown" is now a Royal grelit. Four second-class battle-ships (two "Centurions," two "Trafalgars") arc also to be laid up. I will not trouble yon with the figures, but if you work out the total reductions, including tho eight "Royal Screreigns," you will find that we are left with a total availablo number of forty-ono battle-ships, although the Dilke Return gives a far higher number. Wo aro told that this scheme is not in operation, - but if you look at tho Narnl and Military column of the Times, you will see that the ships aro being withdrawn one by one. That, to my mind, is causo for alarm; 'but we are told that thero is no causo for alarm bccauso of the formation of the new Home Flect, on which Admiral BowdenSmith sajs there may bo some reason for argument. To my mind there is ver: great ieason for argument. Tho Admiralty declined to tell us what ses training is afforded by the Hono Fleet, how much it is, how many men aro to be allowed to each ship, how often the ships are going is sea, and.even declino to tell us what the ships are that compose it: There is only one conclusion to be derired from tho Memorandum, namely; that tho ships aro kept in harbour, and that the men aro liept on a half, or perhaps a quarter, training. Under tho present system of nucleus cicws, tho men only go to sea ten days a quarter. As far as tho reservo is concerned, the reserve proper is kept to reinforco tho fighting line, and $I$ do not know that there is rery much objection to that; but if ro reduce the sea-going squadron in order to swell the reserve, with perhaps a clight increase of sen training, consider what that means. Tho preainble of the German Nary Act lays down as an absolute axiom that the only possible way of keeping ships efficient-is to keep them at sea in full sea training. I havo not-tho honour to belong to the Naral Service, but I have norer yet had a conversation with a naval officer who has not said that the only way of maintaining a ship in an efficient condition was to keep tho men at sea under training. I should also like to mention, with regard to the personnel, that the entrics for tho Royal Naval Reserve have been entirely stopped, as you will see by reference to the last. Naval Fistimates. I should also like to call attention to the short serrice system with regard to tho personncl, by which men, instead of being enlisted for continuous service of trelve and nine years, are being cnlisted for twelvo jears, only fivo of which is spent in active service, and the remainder in the reserve. I belicve that the naral offecrs present will agree with me that it takes, on the arerage, five years to mako a man efficient. Theso men, after five years, are passed out on sixpence a day pension! Sirpence a day pension is no use to him; ho must get a job. Ho is an unskilled labourer ashore, whaterer ho-is at sea. Where does he go? He goes to the Unitcd States Nary. In addition to the short scrvice system, there has been introduced lately, under, I am sorry to say, a Unionist Governiment, n system of inviting continuous servico men to break their service at any time thoy like, and to pass into tho Royal Fleet Reserve. What docs 
that mean? It means that those men also go to tho United States Navy in largo numbers, where they get from three to four dollars a day. Wo are training first-class seamen and gumners for tho American Nayy; that is what it comes to. Why? In order to save pensions, and for no other rcason whaterer. That is stated in the last Naval Iistimates-in order to save the granting of pensions to men who have deroted the best sears of their lives to the service of this country. Wo have also heard that the Constguard is to bo abolished. The statement has not been confirmed-nor has it been denied. That will mean that over 4,000 disciplined men-tho finest in tho Serrico-will bo, in a few years' tine, no longer availablo as a reservo force. I do not see where the saving is effected. The Coastguard duties must bo performed by some borly of men. Tho cost will nut appear in the Naral Estimates, but it will appear in the Ciril Estinates, and therefore it is called an economy! Tho last point to which I want to call attention is the fact that tho Iroyal Marines have been reduced by 1,529 men-tho Royal Marines, a corps second to none. I would liko to remind you also that two years ago a proposal mas mado to abolish the Royal Marines altogether. I camnot tell you the circumstances under which tho proposal mas negatived. It was, however, negatived by a high authority. With regard to the question of the lnch of cruisers, I hopo Admiral Fremantle will give us his viens on the subject.

Vicc-Acimiral Sir Cirnnes Cayrpale, K.C.M.G., C.B., D.S.O.:-I only rise in order to add my testimony to that of the other speakers of the extreme pleasure mith which I have listened to this extraordinarily rell-written paper, which has been put before us in such a wonderfully clear manner. In the courso of his lecture, Lieutenant Bellair's referred to historical retrospect. I do not think ho quite knows what is dono at Greenmich. In the courso at Greentrich they are all taught naval history, which I consider is a most important point. You cannat obtain a glimpse of the future except through the medium of the reflected past. That is a v'ry rell-known maxim. It is only by studying history, and bcing well $u_{i}$ ) in ererything connected with tho Nary, that you are able to las domn lines upon which you can travel in the futuro with safety and economy. With regard to tho tro-Power standard, of which so much has been said, so far as I am concerned; I am a three-Power standard man. Of course, wa havo to remember tho public purse, but where it is possible there is not the slightest doubt that that should bo our position:. I am one of those who do not consider that trelvo ships make a flect, and $I$ hare endearoured in this Institution and elserhere to prove that. Besides the actual ships that are required for fighting purposes we must also have celliers, ammunition ships, hospital ships, look-out ships, and all the paraphernalia that gocs to make up a flect. If me ment to mar to-morrow we should have to take up all these things probably haphazard.' I think myself money should be spent-long beforehand in practising these ships with the fleet, and, generally speaking, making tho flect mobile, as it rould be in an actual fight in time of war. There is only one other point I would like to mention, that is, that $I$ an also one of those who do not think we should depend on the English Channel as our only was of getting into the North Sea. I am of opinion that this little island ought to be cut across from Ndinburgh to Glasgow, nnd that wo ought to be able to transfer battle-ships from the North Sea to the Atlantic by means of a canal, or keep them inside in a loch if liecessary. I am a very strong advocate of spending tho nine to ten million sterling required, I bcliove, to cut the canal from Edinburgh to Glasgow. I beliere it is a 


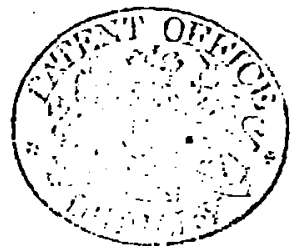

THE STANDARD OF NAVAL STRFNGTI.

point of strategy which would be worth orer a hundred millions to this country, and would bo a great saving of naval strength to us. I hope before I get out of it $I$ shall see that done. The other point I wish to raise is rather a debatable one, but $I$ am very strongly in favour of the idea that wo should have means of transporting troops to the Continent ather than by orer-sea; that means, of courso, the Calais-Dorer Tunnel, which I also hope to see made. I think that would be a fairly strong strategic point. If we could transfer troops to a friendly nation on tho Continent by means of such a tunnel, if we hud a difference of opinion with some other nation, we should not require such an enormous fleet of transports to carry the troops across tho sen. . You must remember that taking ships across tho sea does not only mean the employment of transports, it menns the use of an enormous flect of convoying ships, which have to be taken from their proper work. I wish to say, in conclusion, how very much interested I have becn in this lecture, and to ackl my thanks to tho lecturer for the excellent way in which he has brought tho subject before us.

Mr. L. Grimas H. Hontod-Syimin, F.S.A. Scot. :-Like everyone else, I hare listened with the utmost attention and interest to everything that has fallen from tho lips of the spcalers up to the present moment, and it is with somo diffidence that $I$ rise to place before sou the riews which $I$ hold upon this subject. I slould like, now, in the first place, if I may, to take ono particular point in Admiral Bowden-Smith's specch-one which at first glance seemed to be a good point--namely, that we need not build as much at the present moment as we should otherwise build, for the reason that the British nation can build more rapidly than any other. Assuming the reason relied on to bo sound in fact (a suggestion the accuracy of which I $\mathrm{am}$ not to be taken as ndmitting), that might be something in the nature of a good argument; but, if I may eay so, and I say it with the utmost respect for the Admiral, he has cut from his own argument the sole basis whereon it rests, for at the close of his specel he said that ho considered it very undesirable (for reasons which ho gave) that we should build rapidly. Now, you cannot have it both ways. Either it is a bad thing to build rapidly or it is not; and if (as would appear to be the Admiral's opinion) it is a bad thing to build rapidly, then you must build in advance, and so, by slower building, secure the sane effect as if you began later and built nore rapidly. And now, coming to the great principle knorn as the "two-Power standard," we have at the outset of this discussion, as it seems to me (for reasons which I will mention in a mement), the presumable fact, or what I should call a prima facie case, that the two-Power standard is being thrown overboard. If me complain, we are asked why-if we are right-does not the Opposition dare to movo the adjournment of the House of. Commons? Is not this, perhaps, becauso tho late Gorernment is itself not frec from blame in regard to its naval administration, and fears the obvious retort which such a motion monld invite? I am not one of those who think so highly of what Unionist administrations of the past ten years have done in regard to the Nary. But it is now noro material to asl: "What has the present Gorernment said and done, what is it doing, with regard to the Nary?" Before coming into office the present Prime Minister stated: "I accept the doctrine of standard of supremacy that our flect should equal any two other flects in the morld." What, now, has been the hitherto accepted meaning of the tro-Porer standard up to the present year? 
It means, not a nere equality with tho two next strongest Powers, but the capacity to meet and beat the tro next strongest lowers; and that ni) doubt is the standard which Sir Henry meant that he accepted. You cannot be certain to beat your enemy unless you have somo margin of superiority. Personally I am not prepared to accept tho 10 per cent. nargin allucled to by other speakers. I agree with Admiral Campbell's riew. Why should tho British Empire, which exists on and by eca power alone, run the risk of trusting its security to a 10 per cent. margin; especially nowndays, when there is plenty of chance of battle-ships being sunk from all sorts of extrancous causes, as was eecn in the recent RussoJapanese war? The British Limpire can afford no risks whatever, and I eeriously question whether a 10 per cent. margin of superiority is to-day sufficient. But assume it is. It is yet to be a superiority as ngainst the next two strongest Powers. That has been and is the accepted meaning of the two-Power standard, and that it is which, as $I$ have said, Sir IIenry Camplell-13annerman accepted beforo ho camo into office; but now- that he is in office ho has closed the book of his past statements, and argues that it is preposterous to suggest that Franco and Germany, for instance, will ever join together. Is it really such a prepasterous thought? If Germany were to choose to square with France on the condition of France taking Belgium without Antwerp, and Germany taling Holland plus Antwerp, there would bo all the foundation of a good square deal in the part of France and Germany; and if they saw their chanco of such square deal, it mas well be that for its purposes the French night sink for the moment their grierance as to the Lost Provinces-; and you may be suro that if Germany (by way of utilising further in her own interests such achiered community of purpose) saw any chance of getting for herself some of those fair places of the earth which the blood and treasure of our forebears lave bought. for us, Germany would tako the first available opportunity of turning that chance into a certainty. Ancl yet we have the Prime Minister saring that he will not look at tho tro-Porer standard if it means a standard as against France and Germany; and all the timo you have tho conditions of a French and German coalition existing. What does the expression "standard" mean? If we are not going to keep to our standard of building so as to be able to meet and heat the next tro strongest Powers, whichever they mas be, what is the use of calling it a "standard" at all? If a thing is stable it may bo called a standard; if it is not it is no longer a standard. If the tro-Power standard is no longer to hare the meaning it has always hitherto borne, a meaning which can be "understanded of the people," a meaning which, clearls understood, enables the country to keep an intelligent eye upon the Admiralty, then not only is it no longer a "standard," but no longer has the country any basis upon which it can intelligently follow and intelligently (if need be) criticise the actions of those who from time to time may be responsible for the Navs. If we are not to discuss the position as against the combination of France and Germany, it would almost appear unreasonable and unnecessary at the present moment to discuss the question at all, except in so far as there may be suggested a passibility of a war between the United States and Germany in union against ourselves, which I confess I do not myself anticipate as rery likely, though of courso it cannot and must not be left out of consideration. Taking, then, the Premier's own statement, to which I have just referred, you have, ns it soens to me, a good prima facie case for suspecting that tho Government 
are, in fact, throwing overboard the "two-Power standard" in its hithertu accepted sense. But thero is more than what I have already mentioned. The Premier was asked in tho House on tho.12th of last November whether the two-Power standard in its hitherto accepted senso mas or was not the policy of his Government; and he declined to answer that very simple set all-important question. Admiral Borden-Sinith has told ns that in his opinion we aro all right at the present moment; $I$ confoss $I$ think wo aro not far from being all wrong. Tho point, however, is, not whether wo aro safo or unsafe at the present moment, but, whether, and upon the adoption of what policy, - me shall be safe in the years to come. Coming now to facts as apart from statements : Do not let it be forgotten that when tho Cawdor Memorandum was issued last year, it was no ordinary Memorandum; the Unionist Government wero putting their heads together to sce what was the absolute minimum that they could safely suggest, and as the rasult of their deliberations it was decided that it mas essential that, we should lay down as a minimum, four armoured ressels in 1906-7, and four in 1907-8 (cight in all), cach to bo built within two jears; yet in May of 1006, with a new Government in power, when nothing had in the interval taken place on the Continent of Europe to make any variation necessary, the Admiralty, through the First Lord, come formard and say that the "country, instead of needing as a minimum four and four (as they had said but a few months earlier) could do with only three and two; that is to say, instead of eight, only fire! And this in face of the fact that both France and Germany havo during the interval brought forward increascd programmas, and the "Montaru" has been lost. I rill" only sdd ono word with respect to repairs. Is it not really alarming to be told and (if it be tho fact) to realise that is per cent.- some say 95 per cent.- of the repairs of the ships of His Majesty's Nary aro left undone to such an extent that largo numbers are not capable of doing the duty they ought to do? Take a single instance (I have not time for more), the "Glory," which, for the reason indicated, could recently steam but 12 knots instead of her normal 18 I I should like, howerer, ere I sit down, to refer to one other matter : the question of cruisers, to which the tro-Power standard has, of course, no application: This question is one which Admiral Fremantle has had under his continuous consideration since 1902, and it is a matter to which me must give jet more and more attention. Is lato as Juno of last year he stated in the public Press that for the purpose of commerce protection alone, to ensure our food and raw material from the hands of the enemy, we require at the present moment (bejond what we, in fact,. passess) "at least 50 fast protected cruisers of not less than 2.1 knots speed" to be "built without delay." That is the result the $\Lambda$ dmiral has arrived at after many sears of thought. It has been suggasted that the result of tho lato manouvres has shom it to bo an impassibility for tho ilritish Empire to protect its own commerce. If that is so, it at least supplias a reason for Mr. Robertson's statenent, that it is not in the public interest to gire any information relative to the results of those mancourres I Ministers of both Parties, when they do not wish to give an answer: to a naval question, say either that the question asked is immaterial, or that it is not in the public interest to gire an answer! But we are entitled to know-and wo must know-whether it is intended in fact that we shall protect our commerce in war. If we intend to do so, then it follows, that if Admiral Fremantlo is right, we must proceed at onco to build for the purpose, as with our present number of cruisers we should, 
cx hypothesi, be unablo to afford the necessary protection. Remember that if our commerce (which includes our food) is insufficiently protected, then, when tho day of war is on us, up will go the cost of freight and insurance to such an extent, to say nothing of "corners," that the cost of raw materials for our manufactures will be cnormously enlanced, while food iteelf will go to famine prices. There will bo both shortago, and simultaneously, enhanced prices. There mill be great distress. MIanufacturers will have to shut down their works; whge-earners in consequence unable te earn any wages at the very moment when food mill bo rising rapidly in price; and there will be grave danger of our being starved into submission by tho outcry of tho poor. I do not think I am putting the case too high. In 1812, when $\pi$ wero fighting two Powers (France and America) at the same time, although, we were at that date almost.entircly sclf-supporting, and although our population then was less than half what it is to-day, tho quartern loaf went ip in prico to 1s. 8d., and biead riots took place in many of our large tomns. liread riots aro next door to submission, for no Government can keep in power and carry on a war if the whole country is in a ferment of discontent, with riots from starvation tho rule on crery hand. Yes, if tho Admiralty means to protect our commerce in the event of war, then it follows that, if Admiral Fremantlo is right, the means for that sufficient protection aro at present non-existent; while, if he is to bo regarded as wrong, it would almost seem to follow that ho is wrong only becauso tho Adniralty has decided that wo are not to be prepared to protect our commerce in the day of war. If that bo so, indeed, then Good-bye to the British Empire!

Mr. Edwand Beatchisip, M.P.:-We have listened to a rery able and a very instructive paper read by my friend, Lieutenant Bellairs; but as wo havo only heard it read and havo not scen it in print, it is very difficult for us really to discuss all the questions that hare been raised. I riso to ask whether this discussion might not be adjourned, so that we might have tho opportunity: of carefully considering ererything which has been put before us, and then wo should be in a better position, I think, to arrivo at some conclusion. If I $6 a j$ a few mords now I hope I slall not be precluded from making some, further remarks on another occasion. Wa lane had both parties condemned this-afternoon by tho last rpeaker; it dees not matter whether the Government was Conservative or Liberal I should like to say a few words rather to justify the pasition of the Liberal party in tho House of Commons at tho present momect. I an perfectly certain that the Liberal party as a whole is most anxious to maintain our naval supremacy, and I think that wo owe a debt of gratitu lo to the lecturer for this paper, because what the House of Commons requircs is to bo instructed on this question, because wo are not all technical people, and then they will bo able to form their omn conclusions as to what is necessary in order to maintain that supremacy. Admiral Sir Nathaniel Bowden-Smith spoke with regard to the question of orertime. I think we are all agreed that, generally speahing, in all work orartino is a mistake, but $I$ do not think it was a mistake rith regard to tho "Dreadnought." The "Drcadnought" was a new ship of a frest ilesign, and we depended on the result that that ressel might show whether we were to build more vessels of that type. It was necessary, therefisce, for us to go on building, and, as I think, it was a wise thing to push forward the construction of that ship and hear the results in every possible way bufore we committed ourselves to building more of that class if r.usel. Therefore $\mathrm{I}$ think with regard to orertime in that case it. was fully justified 
I mas glad to hear Adpiral Bowden-Smith say he thought me had quite a sufficient number of battle-ships at the present time. The Admiralty Memorandum of $100 \bar{j}$, under the former Gorernment, did lay it down that we wero to have four armourcel ships built cvery year, but mo are laying dorn now theso very large ships, and we want to linow whether other nations are going to follow us in that direction.

The Cmarrax (Admiral Sir.R. H. Harris):-With regard to the suggestion you hare made, Mr. Beauchamp, I think it rould to desirable, as there are four more gentlemen who wish to spenk, if we pastpono the discussion till three o'clock to-morrow. 'That would give a better opportunity for. summing up tho question, and time to think orer the valualsle points which Iientenant Bellairs has brought before us. So I will ask you to finish your remarks now, and wo will adjourn to to-morrow at three o'clock.

Lieutenant Cancrox Beidans :-I do not rise for the purpose of replying to the discussion, but I wish to say, with regard to the point which has been made that my paper was not in your hands before the meeting took place to-day, that you are in precisely the same position as tho Members of the $J$ ouse of Conmons when the Admiralty makes a great change in policy. On the 2ith July we had this great change in naval policy sprung upon us in a speech at a week-end and at the back-end of the session, so that. now you can better appreciate how we are circumstanced for tho discussion of great changes in naval policy when thes are brought forward in the House of Commons. No notice whaterer is given.

The discussion was then adjourned, and resumed on Friday, 6th December. Admiral Sir R. H. Harris, K.C.B., K.C.M.G., in the Chair.

Commander C. Cnutchier, R.N.R. :- I must apologise for the nossession of a voice like a crom this afternoon, but $I$ can assure you $I$ hare not come here to croak. There nro only a few remarls I wish to make. I should like, in the first place, to emphasise my p'easure, as an old subscriber to this Institution, at talsing part once moie in a naval discussion in this theatre. They have been too conspicnous by their absence for the past few years, but I hope the interest this paper has excited may lave the effect of bringing together some nore of thase interested in the $\mathrm{Nary}$ to discuss matters and to give tho public some insight into what is being done. I think the discussion yesterday afternoon was particularly useful, because it shomed that there is a rising sclool of young men who are beginning to take an interest in the Navy, and-an intelligent interest. 'That is a thing that might very well be enconraged. There appears to be an idea that it is possible to run the British Nary on cheap lines. I do not think that a more fallacious doctrine could possibly be enunciated. The Navy is not a cheap instrument. In the hands of the British Empire it has to be capable of fulfilling its duties, and it must be adequate for tho rorls it has to perform. There was a time when the British flag flew over every sea, when wo wero represented in all quarters of the world; but I fear that in the last, shall $I$ call it, mad craze for cconomy 
in connection with the Nary our flag has been withdrawn from many places. There are plenty of people in this theatre who have experienced the feeling it gave us when wo went into any harbour and saw the white ensign flying on even the smallest gun-boat that erer flew the British flag. That was a national asset. Under the new redistribution that national asset scems in a fair way to disappear. There is another way, however, of looking at the matter. It is necdless that I should dot the i's and cross the t's when I say it is far casier to withdraw ships from a station than it is to put them back again. Our friends te-day may possibly be oul focs within a measurable distance of time. I do not particularise cither the Lastern side of the world or the Western side; but the fact is, that on both sides we have withdrawn garrisons and fleets which it might be difficult to replace without the danger of complications. I feel confident it is unnecessary I- should particularise what is at the back of my incad in maling these remarks, but $I$ would most earnestly put formard the statenent that the withdramal of ships and flects is an easy matter, and the replacencnt of them an entirely different thing. To come now to tho paper. In the opening part of it I fincl these renarks: "The people lack an historic sense, and no attempt is macle, as is donr in Germany, to cultivate it in the scliools of the country." I must, with every deference to the lecturer, entirely differ from that, and must point out that the Navy Ieague for the last. ten or twelre years has been working in schools, and if I might ask for these papers to be passed up to the Chairman, I think they will shor, at all events, that considerable progress has been made. The list of tho examinations for prizes at the end of that collection of leaflets will show considerable progress in the principal educational establishments in the country. To turn to tle Appendix of the paper under discussion, which eren now, I regret to say, I have not had tind to study properly, there is there a collection of valuable detril, which mould, however, puzzle ansone execpt those who have given the subject the very greatest consideration. In fact, if the ordinary reader tries to analyse ships, their dates of launching, their dates of completion, he gets into a most hopeless complication, and I rould most carnestly ask that mlen this question is being considered, the rery plainest issues should be put forward before the people. In this particular relationship I should like to say-and I feel sure my remarks will be endorsed by nearly everyone here-- that we may assume at the present time the strength of the British Nary in its matériel is perhaps equal-I might say fully equal-to the two-Power stanclard; and if we mere to say, further, that as it is at the full Power standard now it must bo maintained at the full Power standard, wo should have something the people would really understand. Still further to endearour to clear up that point, I rould say that' we have one "Dreadnought" now, and the "Dreatnonght" is presumably the ship. of the future. It is then absolutely essential that when the Nary Estimates are presented, they should put before Parliament the "Dreadnoughts" laid down, or the equiralent ships to the "Drcadnought" being laid down, by foreign countries, and then that our shipbuilding programme should bo equal to those, with that fair margin of reserve which has been held by hoth parties to be indispensable for the safety of this country. Yesterdiy afternoon Admiral Fremantle, wlom it is needless for me to say carries the respect and admiration of us all, epolse on the subject of cruisers. So far as $I$ can see we are building no cruisers now, except the three monster oncs which are called indifferently either cruisers or "Dreadnoughts." I should like to enter a plea for consideration, 


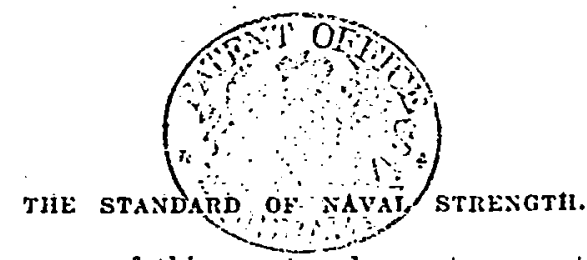

Whether tho commerce of this country does not warrant the lajing down of cruisere, either armoured or protected, that can fetch and carry, ressels to do tho housemaid mork, if I may so phraso it, under tho condition of war. In war we should want numbers of them, but $I$ fen $r$ at the present time their supply is wholly inadequate.

Mr. Fowamd Beacchasr, M.P.:-I think that come of the observations which I propose to mako have already been dealt with by tho last spealier. As far ns we aro concermed at present, I think there is no donbt that in battle-ships alone we aro fully up to the two-Porer standard, and that thero may be satisfactory reasons alleged why we should for tho moment mark time. That is merely looking at it from the point of view of the present moment, but $I$ think we have to looli vers much further than that; wo havo also to look to what tho other lowers proposo to do. Wo have at the present moment tho "Dreadnought," whicl is supposed to be, and I hopo it is, tho finest battle-ship in the rorld, and tre are laying down threo more of thoso ressels this year and two at least next year, and perhaps a third one, dependent, of course, on the result of the Hague Conference. Then, when these ships are built, we shall be ahead of all the other nations-certainly of any one nation, and I think of ans tro nations - wo shall be ahead of them in having the finest battle-ship flect in the worlu. And besides that we have those ressels which I rentured in the House of Commons to criticise, the large armoured cruisers, which are said to be equal to battle-ships. I think they must bo in some rray, at any rate, inferior to tho "Dreadnought," but $I$ "think they are far superior to anything which re require in the way of cruisers. I do not believe that you can successfully handle something which has a double object; you ought to have a battle-ship or a cruiser. But beyond that, Iocking ahead, wo havo to consider whether we shall not in the near future liare to build a considerable further number of battle-ships, and whether is: is not more efficient and really more econonical to have a regular programme for the building of battle-ships than to build three one year and seren in another sear. We heard yesterday that, in consequence of our present system or new system of recruits for the Nary, after a man had become efficient he was passed out of the Service and found occupation in another country. 'I think that also holds good with the artificers and peoplo who work upon the building of ships. They must have regular employment, and if you have to put a number of men on at a particular time for the building of a certain number of battle-ships, and then reduce that number aftermards, you must necessarily thror a large number of men out of einployment, anr' hose men have to find employment at other places, and $I$ think there aro other countries-one country in particular-which will be very glad to hare our first-class rorkers. With regard to the cruisers, I was very much surprised yesterday to hear from Sir Nathaniel Bowden-Smith that ho thought we have a sufficient numbers of cruisers. $A$ largo number of cruisers me have mill in a rery short time, I believe, become perfectly obsolete and be put upon the scrap-heap, and that will leave us with a very great shortago in aruisers. I remember when Sir Geoffrey Homby read his paper beforo the London Chamber of Commerce in the year 18s8, he distinctly laid stress on the number of cruisers mhich it was necessary for this country to have, and he said : "You mas have to watch a particular place, and it is necessary to hare three cruisers on tho spot in order to do it. If sou have three cruiscrs on the spot it will be necessary to hare five cruisers in order to carry out that mork efficiently." That struck mo 
very much at tho time, and I sincerely hopo that in the near future tho consideration of the commerce we have to protect and the attention that is being given to tho problem by tho Admiralty at the present moment will result in tho building of more cruisers. It is always rery difficult, I think, to obtain any rery great amount of information in answer to questions that miay be asked the representatives of the Admiralty in tho Houso of Commons. I saw it stated a littlo timo ago in tho Standarl that all tho ships of tho "Royal Sovercigil" class were going to be put into special reserve, and that they nould have simply skelcton crems. I asked the question whether it was so, and the reply which I received was somewhat cryptic. Tho answer was: "I am not in a position at the present time to gire any information; as the scheme for the re-arrangement of the ships in commission in reservo is still in process of development." I do not know what that development may be, but I saw two days afterwards, and it was said to be an official statement, that two ressels, at anj rate, of that class had becn placed in the special reservo with skeleton crews. Now, I think that if tho Admiralty have tho intention-and $I$ rather fancy that they have-not.to spend any money or much money on the maintenance and upkeep of theso ships, it will bo fair to us and faicer to the country to let us know exactly what they do mean. Of course, wo have their own statemerit of the Admiralty policy on tho Nary for 1905. What does it really mean to put these slips into conmission with a slieleton crew? It means practically, according to their own statement, that sou aro getting rid of these ships as efficient units. They were speaking of the old system, where a ship was paid off and the crew dispersed and another crew turned over to it. That nas suddenly to extinguish certain units of organised efficiency. i ship manned by officers and men who neither linew the ship nor lonew each other, it was said, could not be expected to reach a standard of fighting efficiency for at least six months. I gather from thạt, that ships placed in commission in special reserre, with merely a skeleton crew, rould, on the Admiralty's own showing, mean that those ships would not be ehips of fighting efficiency for at least six months. I think that perhaps less timo than that would give us ships of fighting efficiencs. But if they are going to place these ships in the special reservo in this way, which has been called tho restibule of the scrap heap, and thoso ships aro going o. to the scrap heap in a fer years' time, I think they ought to let us know, and we must continually insist that these ships that are going out of employment should bo replaced by a sufficient number of newer types of rassels.

Sir Willias Winte, K.C.B. (late Clief Constructor of the Nary):I feel some diffidence in joining in this discussion, not that it is a subject in which $I$ am not interested, but because there is a danger of ansthing I may say being attributed to partiality on my part in favour of shins which I hare designed. But I do not propose to discuss designs of ehips, and propose to join in this discussion because it is a matter for congratulation that a naval delate should again take place in this theatre. Of lato there has been a tendency to suppress discussion, to state ono set of opinions strongly, and it is time another courso was taken. Lieutenant Bellairs' paper trarerses so much ground that it is absolutely impossible-neither would it be desirable-for mo to tako up scriatim the various points. He has spared no pains to ascertain the facts; ho has summarised those facts, formed his conclusions, and stated them definitely. We know what ho means, and wo are bound to respect 
his opinions, even if we dissent from them. I will first refer to matters which concern me as a naval architect, not as the designer of particular ships. First, there is the question of displacement tomnage. Eversbody: here knows that the displacement tonnage of a. ship means her total weight when floating at a fixed water-line, which may not be the deepest load water-line, and for most war-ships is a long way from the deepest load water-line. For any assigned draught of water it is possiblo to ascertain the weight of a ship when you know her form. The lecturer properly says that merely to add up displacement tonnages of ships on the -effective lists of different flects and to take the respectivo totals as measures of relative figliting force is incorrect; in fact it is absurd. 13ut there is an important scriso in which displacement tonnage is a fair and useful measure. At any given date, when inrention in relation to warliko material and structural arrangements has reached a certain point, one may be sure that if one naval architect is able to use 14,000 tons as his capital, and another naval architect, equally well informed and equally capable, is only allowed 12,000 tons, the man who has 14,000 tons must have the adrantage. The distribution which may be made of the greater tonnago may not be unirersally approved, but it cannot be denied that if one man is working with 14,000 tons and another with 12,000 tons at a given date, he ought to produce a better fighting machine. Recognising that limitation, in comparing ships designed at or about the same date the displacement tonnage method is useful. For example: Going back to the Naval Defence period of $1889-9$, I was responsible for advancing tho displacennent of battle-ships to $1-1,000$ tons at a time when other Navies kept much below that figurn: and undoubtedly we got good ont of tino larger displacement. Adrance in displacement does not alyays mean a corresponding or proportionato adrance in cast. Is a matter of fact, ":o built the "Royal Sorereigns" for less money than the "Inflexiblo" cast, although she was of less displacement, and for not much more money than many smaller foreign ships were costing: Therefore, sou may take it as a principle that ships of a given date which are of larger, displacement ought to bo more porerful fighting machines. In that respect, since Great Britain led the morld with large displacements, there ought to be, and I believe there are, corresponding adrantages which I need not particularise. On the other hand. if a ship of any selected date is compared with a ship designed long after, when inventious in gunners, in armour, in propelling machinery have gone further, it may happen that the ship of carlier date may le more powerful than the ship of later design, because of her smaller displacement. We have generally been building larger ships than were built abroad contemporaneously, and this fact is important. We have had the necessity for greater sea-keeping power, greater coal endurance, and have produced real sea-going ships, not merely floating forts, stch as have been designed and built for coast defence or for employment near the coasts of other countries. Although it is true that the design of later date lans many advantages, it may still happen-in many cases it has happened-that ships of earlier date, because of their greater size, are more porrerful fighting machines than later ships of smaller size. One cannot lay down any general rule, and exact comparisons are difficult. I do not like to refer pointedly to foreign vessels, but $I$ have in mind ressels of about 11.000 tons belonging to a foreign Nary, built somo years after the "Royal Sorereign" class. In those ships defence was deliberately minimised and powers of offence wero increased. The hull armour consisted of a narrow belt not extending over tho wholo length, and this belt only roso about 2 fect above water 
when the ships were fully laden. Above the belt there was simply thin steel plating. These foreign ships had tho adrantage of modern armour and of other improvements, in propelling machinery and guns, introduced in the interral between their design and that of the "IRoyal Sovereign" class. Yet I say unhesitatingly that the "Royal Sovereign" class mero still tho more powerful fighting machines. No general law or simple rule can be laid dowi for these comparisons. One must not trust tabulated statements of maximum thicknesses of armour. There are ships in which the reputed thichness of armour can be found only on a few plates on the sides; such things are not unlinown cren in modern times. We must have full knowledge in order to make true comparisons, We know the faults of our own ships, and there is a tendency frequently to exaggerate these faults." That may be tho safe course to take in estimates of relative fighting power, but it may be carried too far; and when talking with forcign friends, I find that they think it has been carried too far, and they say it is clever on the part of English writers to depreciate whant wo possers in order that the public may be Ied to believe that we are not'so well off as we really are. Turning next to unarmoured ends, one finds a discussion which goes back for more than 30 yenrs, and one gets a little weary of it. It reappears periodically, especially when the Royal Nary is relatively strong. I Lientenant Bellairs says we are all right at present as regards naval force, and, being well off, the adrocates of large building programmes recur to tho subject of unarmoured ends as a source of weakness. Admiral Fremantle yesterday said that naral officers had always opposed unarnoured ends; but by reference to Parliamentary Papers for 1889 one can see that it was a Naval Committee which was associated with tho Board of Adniralty in considering altermativo designs who decided unanimously that the ends of the "Royal Sovereign" slould te unarmoured. Alternative designs which I had prepared had the bows armoured, but these were deliberately ect aside as being, in the opinion of the naval officers consulted, not so good as the design with unarnoured ends. The reight of naval opinion at that time led to the disposition of the armour adopted in tho "Royal Sovereign" clnss. For every ship that has been designed subsequently the same question has arisen; rarious alternative designs have been put before the Board, and the arrangement of armour which has been adopted in every instance was selected and approved by the Board. Armaments hare changed, Q.F. guns hare come into use, other conditions have been modified, but writers and speakers who concentrate attention on the absence of armour from a certain portion of tho ends of ships, are apt to orerlook considerations more vital to tho safety, buoyancy, and stability of ships. The small rertical extension of armour to the ships in foreign fleets is not regarded by them, although it involves serious dangers. In many first-class foreign ships the armour belts rise only 18 to 24 inches above water when the ships are deep lade 1 . Above the armour belt there is nothing between, the interior of the ships and the outside water except $\frac{1}{2}$ inch of steel; in inany cases there is no sub-division of that internal space. Frequently heary guns are placed in armoured barbettes, perhaps 20 feet to 30 feet abore the water, and these barbettes are only connected $\pi$ ith the armoured hull by armoured tubes. I ask whether or not such a limitation of the rertical extension of the armour is a less danger than the limitation of its Iongitudinal cxtent to, say, two-thirds of the length of the ship? The point for consideration is: Which is, on the whole, tho better disposition of armour, within fixed limits of weight. My riews on the armour question are not at present under discussion; we aro talking about principlos. My views 
baro been expressed, and anjono who cares to read them can do so and agreo or disagree. But the problem in every caso in this : Given a certain availablo weight of armour, in what way will it bo best distributed for a particular ship? Each ense has to bo considered on its merits. I will refer to one illustrative example in the Freuch Nary, which I can do without offence, because it las been publicly discussed in France. Vessels of tho "Montealm" class are fine, upstanding cruisers, designed by my friend, M. Bertin; but in some of the first vessels of the class, wherein the hull armour rises about 8 or 9 feet above water, the guns are placel 1 deck highier, and there is an unarmoured space below the gun stationis open to serious attack by shell fire from Q.F. guns. This feature ras soverely criticised, and has been altered in luter ressels. This case illustrates the necessity for taling all circunstances into acceunt in considering the relative protection of war-ships. We do not usually knoir, when attempting comparisons, as much about foreign shios as we know about British ships. This is especially true of late. We live in an age of secrecy. It is considered that the British public should not know what armour is carried by new ships building for the Royal Nayy. I do not in the least agrec with such secrecy, and $I$ never faroured it in my long official carece, and am confident that thoso who wish to know tho particulars for British war-ships can and do know at early datos after building begins. Let us live in the open as much as we can. There are many things we should not disclose, but to conceal the gener al dimensions of a ship or to treat her armour and armament as secrets after construction has berun is ridiculous. I should liko to refer to remarks made in the paper with regard to the battle of Tsushimat $\Lambda$ good deal is made of what hapnened to ships with unarmoured ends; but did thoy faro more than tho "Suvaroff" or tho "Emperor Alexander III.," which had complete armour belts? The Russian accounts sh.ow that although inany ships had complete belts, that armorr was of no usa. Tho belts mere narrow near the bow and stern; but eren if the armour had been carried 7 or 8 feet above water, when ships are driven head to sea and the light sido plating is perforated, large quantities of water will enter. Having nado a careful study of the rhole of the data, so far as I can reach it, and consulted Russian, Japanese, French, Italian, and other authorities, I am of opinion that the sinking of these great ships at Tsushina was duo principally to injuries in their thin side plating and protective decks. Water came in above the armour, the decks, haring large areas; presented magnificent targets, and through injured portions of the decks the water passed below; the ships plunged head foremost, a il mere orerset. To speak of a mere continuation of tho armour to the bow of a slip as being in itself an immense increase of safety, and to pay no regard to its very small vertical extension nbore and below water, is to beg tho whole question, as anyone familiar with the conditions of stability in ships will admit.

A Mejrafr :-May I ask you to express an opinion on the excuse giren for placing the "Royal Sorereign" class, whose ends are unarmourcd, on the non-effective list?

Sir Wriniay Wrire :-These ships aro my children, and I am, perhaps, a partial parent. A time comes, no doubt, when every fighting machine must bo put asido; but $I \mathrm{~nm}$ far from believing that time lias como $x$ ith the "Rojal Sorercign" class. Passing on to the question of progress in invention as affecting war-ships, 1 take exception to an opinion expressed 
by Lieutenant Bellairs on page 4 of the paper. He speaks about turbines as if they involve increased consumption of coal. It is true that at the outset turbine engines of great power when run at low speeds rere expensive of coal. It is also true, as anyone will seo who will study more recent trials with auxiliary turbines, that thes are not now relatively expensive of coal. The steam turbine is an invention which must sustain derelopnent as time gocs on, but already a point has been reached when it compares farourably with reciprocating engines as regards consumption of coal, even at cruising speeds. With regard to rater-tulse boilers and their more frequent renewals, I am inclined to donbt Lieutenant Bellairs' opinion; much depends on the type of boiler and the Freatinent it receires. If the type is riglit and the treatment is reasonable, there is no reason why water-tube boilers slould be costly in maintenance. Inrentions, to be of, real service, must be treated wiscly. As an invention progresses, management must become more skilled. That has been so in machinery rooms, and it must be so in boiler rooms; there is 'no reason why it should not be so. Risks necessarily run are not on one side only in contests betwcen nations. Take for example water-tube boilers. Is long ago as 1892, the French, who mere by no means given to taking unreasonable rishs, had come to the conclusion that the balance of adrantage lay on the side of water-tube boilers, and they adopted them. That meant a gain of a knot in speed with battle-ships as compared with ships having cylindrical boilers. On $m y$ visits to France $I$ found out the condition of things; it seemed to me their action necessitated corpesponding action here. We might not adopt French methods, but when inproved steam generators were discovered and adopted abroad, clearly the problen required to be dealt with here. And we had to deal with it on a large seale. Wo had to leain our lesson as we went along. There were troubles, which happily now have been largely orercome, and which I believe will erent unlly entirely disappear. The main contention of Lieutenant Bellairs relates to our shipbuilding policy. Elsewhere I have dealt tith the conparative rates of building in Fingland and abroad. I will simply add that finance really rules rates of production. To build fast you must spend a lot of money. I am not referring now to phenomonal performances of which we have heard recently; I am referring to our normal procedure. It is truo generally that plenty of money must be spent, and that there must be good organisation, skilled men, materials to hand, and everything arranged if you wish to build war-ships rapidly. The cost per unit of war-ships is growing. It is quite clear, therefore, that financial considerations will become even more important in future. With a given expenditure fencr ships can be built rapidly if they individually cost more; and to maintain both rapidity and numbers, the annual expenditure must be correspondingly increased. That is a game we can play, and havo played. Wo have been at financial war in naval affairs for the last 20 years; wo hare mon because we have been bold and courageous; we have never failed to match what was likely to come against us; wo should not fail in future, and are not failing at present. Let us take the pronounced intentions of France and Gerniany as disclosed in their Naral Estimates. What do we find? Licutenant Bellnirs has said that at the present moment we are all right. It is a comfort that he should have that fecling. Ho wants to keep us right; wo all want to keep right. We can beliere that of the present much-abused Gorernment. I di) not believe any responsiblo British Government would do anything elee. I entircly dissent from the doctrine that only the latest type of ship counts in naval affairs.

VOL. LI. 
Tho Crisinsss: :-That is not set forth in the paper.

Sir Wild.uss Winte:-I dicl not say. it was; but tho viow is often put forward. 'laking it on that basis, and admitting that wo aro at the present moment in a good position as regards naval force, while we have a large shipbuilding programme, it is well to note carefully the intentions of France and Germauy, disclased in their Naral Estimates. The French Naral listimates, including the detailed financo for 1907, have been in $m y$ hands for more than a month, and I have gone through the whole of the figures thoroughly. The French intend to finish two battle-ships by the end of the year 1910. There will be a lot of money to pay after that, but the sfips will be ready, although the final instalments are to be paid in 1011. Four other battleships are to be ordered this year, but are not to be laid dowin; they will be finished, according to the latest statements, in the middle of 1011 . In the United States there mayibe two large battle-ships completed by the cnd of 1910. In Germany the threo armoured ships proposed for 1906 are not yet begun. German authoritics have found, as everyone does, that when a new type is to be built it is worth while taking trouble and thinking out arrangements before starting work. Supposing they start immedintels, according to their programme they will take three rears to build the ships. It is not a question whether they could build more quickly, but what they proposo to do. What shall we have ready at the end of 1909 ? The "Dreadnought" is now approaching completion, and we are told sle is equinl to any four battle-ships.

\section{A Meaner :-What is your opinion on that point, if I may ask it?}

Sir Williass White:-I would rather not answer! I did not come here to give opinions on types of ships. We shall have also the "Iord Nelson" and the "Agamemnon," ships which compare well with the new type of battle-ships to be built in France as regards armour and armament. "Ihen wo have threo "Invincibles," which a previous speaker eaid were "quick-ehange" ships, appenring sometimes as cruisers and sometimes as battle-ships. It all erents, in armament, eo far as the published descriptions go, the writers of which seem to be well informed, they are armed as battle-ships, although no official statement has been yet made respecting their armaments. Lastly, we shall have three new "Dreadnouglits," two of which are already in hand and one about to be laid down. I think Lieutenant Bellairs will agree with me that these will be ready.

\section{Lieutenant BeLLAIrs :-Yes.}

Sir Wirliny Wirte:-So that iso shall have nine ships by the end of 1009; Germany might have three, including one large cruiser. These newest ships, we are told by those who profess to speak with authority, are the ships which will determine our fate. If we can build, as I maintain we can, more quickly and in larger numbers, and if our position in this new and much advertised type of ship at the end of 1909, will be as $I$ have stated it, it is quite clear that we can slecp in peace for another rear.

Vice-Admiral W. H. HExbensos:-I think if you will look at $\Delta$ ppendix G you will perceivo the exceeding difficulty of this country, under any standard that may be laid down, sticking to a programme. It is not only that the political strategical situation alters, but the nations concerned, with tho exception of Germany, vary their shipbuilding programme from 
year to year. Programmes are of recent date, and really the only nation that has strictly provided a consistent one is Germany. I think, if I remember correctly, that both in the House of Commons and the Press, after the 1888 and 1894 programmes, strong objections were urged to programmes. Those objections were put forward at the time, and, as Sir William White says, "finance gorerns the question." The House of Commons is, I feel, reluctant to grant moncy in adrance; it does not like binding itself to the future; it prefers always to lare the Votes taken year by year. In every single instance, whether it is a small detail or a large detail, it carries out that policy as closely as it can. I mould observe that in any business, whether it is a private concern or whether it is a national concern; you must. trust somebody; you cannot get on without it. In the present case the watch-dog we have to trust is the Admiralty. The Admiralty in the past lave show in that they are worthy of tife nation's confidence, and $I$ do not care whethre it is this Admiralty or any future Adniralty, or. whether the Gorcrmment for the time being is a Conserrative Government or a Liberal Gorernment or a Labour Government; I e.m perfectly certain that the Admiralty may be trusted to sing out if there is the slightest danger of the nation getting below par in its naval strength. I lo not think we need be afraid. They are the people whose business it is. They have the latest and most accurate information; they have a heary responsibility. When Lord Tweedmouth publicly says that he will not_allow the Nary to get below par, I think the nation should be satisfied. I do not wisls to deprecinte in any sense the value of the paper that Licutenant Bellairs has given us; $I$ consider it is a most raluablo and interesting paper, aliko to the public and to eversbody concerned, and it must be a great advantage, for papers and discussions of this sort do a great deal of good if it is only in leeping our watch-dog (the Admiralty) from having forty winks. There was one point mentioned sesterday in the discussion that I should like to say a few mords about, namely, the question of overtime. Ycars ago the dockyards were very expensive in the matter of orertime, and I quite agree with what was said, that orertime is not worth the money that is expended upon it, and that for three reasons: First of all, it kecps other men out of enployment; sccondly, it unduly increases the hours of work; and thirdly, it is true to say that I to not suppose in most cases you get half tho value of the money spent on it. That is a general conclusion that all will agree with, I think; but to show you that efforts hare been made to reduce overtime, I can give you figures for Deronport Dockyard. The overtine spent in 1002-3 was £28,391. $I$ set my face agninst it, and in $1903-4$ it was $£ 18,035$; in $1904-5$ it was $£ 13,216$; and in $1905-6$ it was'down to $£ 8,337$. I would make one exception lo the question of orertime as it has been in use up to date, namely, that when you want to build a ship very ripidly it is absolufely essential to use it under the conditions which have pre-existed; but personally I am strongly in farour of shifts instead of overtime where pressure is necessary. With the electric light in tho dockyards, and further improvements, I have no donbt that, although naval architects have opposed the shift system of ship construction, the facilities will be so great that thes will be able to undertalie it. The Admiralty, I-may say, within the last sear or tro have very much set their faces against orertime, and I hnow that recently at Deronport there were constant reminders to us that no orertine was to be utilised.

Fleet-Surgeon W. G. Flouse, R.N. :-It will le perfectly obvious to. cvery exceutive officer that as $I$ am but a seafaring physician I cannot know 
spend mones on everything, and you do not want so much excess in matéricl in that case.

Commander W. F. C.uonse, C.B., R.N.R.:-I should like to express my appreciation of this rery able and raluable paper, which has no uncertain ring about it, and is an cmlodiment of Imperial and patriotic ideas. While we require an efficient Army adequate to our needs in time of peace, and capable of rapid and large expansion in time of mar, no one can deny the fact that by the Navy the limpire must stand or fall. Now, what is tho British Nary? Why, simply our great national insurance, and I venture to assert that if we spend thirty millions a year, or even more, upon it, the premium is but a comparatively small one, when w: take into consideration the cnormous interests inrolved. Personnlly I am one of those who maintain that the Services, whether naval or military, should be entirely above party, but I am afraid that they are too often made the shuttlecochs of politicians and their party exigencies, the real interests of the Empire being neglected or lost sight of. The lecturer has given us a table slowing the time occupied in building certain classes of IBritish battle-ships and the time occupicd in building certain German battle-ships. The "Canopus," "Formidable," "Dunean," and "New Zealand" classes appear to give an average of a little orer three years and six months, while for the German ships given in the same table it is only three years. The "Dreadnoughte" has been built with great rapidity, but the question is, how often wo could go on repeating ships of that description in the same time. Would the armour be forthcoming? Would the guns be reads? I think that is a question that should be definitely answered. I have just had a memorandum handed to mo in which it is pointed out that the German battle-ship "Schlesien," launched last April, was put afloat in less than six montlis from tho date of her first keel-plate being laid down; and yet it was stated in the House of Commons that we could give the German shipbuilding sards cighteen nonths' start and then catch up with them. Iicutenant Bellairs has alluded to the coming Peace Conference. I am not a believer in either Peace Conferences or Pence Societies. I have read some of the drivel emanating from the latter, and I do not suffer fools gladly. Undoubtedly tho best guaranteo of peace is the being preparcd for mar. A few years ago we lind a Peace Conference at the Hague, and we were told that it would inaugurate an era of arbitration and unirersal peace among the mations. But what did we see? Why, in a very short time the outbreak of the Russo-Japanese war, a conflict of gigantic proportions. We are now within measurable distance of another l'eace Conference, and $I$ am already wondering in which direction wo shall next hare to look out for squalls. It is understood that at that Conference a proposal will bo put forward with a view to exempting private property from crpture at sea in time of war. Such exemption would be a delusion and a snare, and rould still bo dependent upon the will of the Power that was strong enough to disregard it. Eren in the twentieth century, war cannot be made with rose mater, and I may quote the words of Clauseritz: "War has but one neans of action-force. Its use is absolute. To introduce a principle of moderation into the philosophy of war is to commit an absurdity." Going further, an absurdity is a blunder, and Tallesrand said that a blunder ras morse, than a crime. But a short time ago re rere engaged in a great strugglo in South Africa, and no war in the history of the world was erer waged in euch a humane manner, although we were told that we made uso. of tho methods of barbarism. Probably we mere wise in our generation, as 


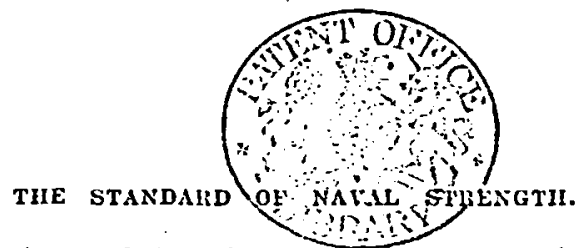

it was the intention to bring the Bocrs under our rule, and we ranted them to settle down quickly after the war was ended; but there is not the slightest doubt that if wo had not formed concentration camps and fed our enemy's wires and children, the war would hare been finished in a much shorter period. For my own part, I do not want to sce private property nominally excmpted from capture at eca in time of war, and, with a Nary adequate to our needs, we shall be rery well able to take rare of ourselres in the future as we have done in the past.

Colonel F. N. M.uude, C.B., Iampshire R.F. (Vols.), lato R.E.:After listening to the most interesting and able specch of Sir William White on the question of the financial bearings of the whole problem, and Commander Caborne's remarlss about the insurance, it comes lome to me that the only way in which we shall erer get the public to understand the importance of the question of defence is to attack them on the financial side. We shall never induce them to tako a proper interest in the subject until we go to the bankers and make the bankers understand what forty-eight hours of war will mean to England. It is impassible to produco reliable fignres, but we can say that our losses would be beyond any one man's time to count or to handle. It is a reasonable certainty that every penny of savings, savings for old age pensions, for insurance funds, ererything we have of that kind, all the money saved in Fingland by the thrifty population, would be absolutely lost, and old age pensions and insurance funds would be broken up by the terrible death rate that would follow on eightecn months of war. I do not mean simply the killed and wounded in battle, but the terrible death rato that would immediately begin in our great centre of population, such as Iondon; Birmingham, Manchester, Leeds, and so on, through the suffering that would crush out all the reaker people who now survive because food is cheap and plentiful. The moment the price of food rises the death rate will be enormous, so enormous that, practically speaking, it is more than doubtful whether any insurance company could pay tho insurances they have granted. Every doctor, I believe, could confirm this. The next point is.: What would happen when the enemy came to Fngland? The whole of the banking reserves of the comnty banks or the joint stock company banks would bo affected. All the banks rely on the Bank of Fingland to sec them through. Of course, there is a good denl of fiction about the bank reserve, and at such times it is possible to get an Act of Parlinment sus: snding the Bank Act; but before it mould be possible to get the suspension of the Bank Act passed there would be, in the case of war, a montl or six weeks of ruin-ruin widespread in every direction, and the existing shareholders in the banks, the directors, and all interested would feel the pinch. Now, instend of playing the "war gaine" as we sometimes do, let us hare a "finance game" for bank manngers and City men, and ask them to seo how they would stand after forty-eight hours' war, with consols dropping three points an hour, as they casily might do. I think when once they had entered into the spirit of that game, playing at so much per point, as thes did in the school which R. I. Stephenson describes in "The Wreckers," where Stock Fxchange gambling was taught as part of the regular curriculum, I think they would realise as they nerer did before what war must mean to them. Then we shall have no difficulty in getting mones for the flect or the $\lambda \mathrm{rms}$. The fleet, of course, comes first. I think you could get men to understand in that way. It is no good merely saying that the results of war will be so drendful that it must nerer occur, as did Lord Orerton beforo the celebrated commission of 1857 . 
He summed up the whole question in one passage, the most magnificent passage of English prose I think I have erer read. In it le showed the extraordinary effect the collapse of the finances of the country would lave in every home in the country, and he wound up with the worls: "The prospect is so terrible that it must never be." From that day forward all funnciers have contented themselves with saying: "It must never be," thinking because they say so the encmy will see it from that point of view too. It is probably becauso that sentiment is well known to Germany and France that for that rery reason the thing will happentley know our weakness, and quite understand how to profit by it.

Mr. A. C. Beck, M.P. :-It is with great diffidence that I rise at all this afternoon; but I thought, as one profoundly ignorant of naval matters though profoundly conscious of their great importance to our welfare as a nation, that I should like to try and put forward very briefly the average'opinios of the arerage supporter of the Government. I was present yesterday afternoon, and, in common with other speakers, wish to thank lientenant Bellairs for his very raluable paper, but I was sumewhat struck with some of the spceches made towards the end of yesterday afternoon's mecting. I think we are perhajp, rather inclined to forget that we are all of us, to a certain extent, faddists, and when I say faddists 1 mean that we all have various points in our mind which we consider of extreme importance. I am happy to think that, as far as I know, almost every thinking man I have met is agreed that the Nary is the most supreme of thase points, but the fact remains that there are many other points also of great importanco in people's minds, and the present Government has been returned, as you all know, with its head full of schemes of social reform. Those echenes of social reform mean money. To take one example : I personally am greatly concerned and interested in the melfare of our agricultural districts; $I$ belice the absence of population in the rural districts is $n$ very grare menace to the future welfare of this country. But if you are going to re-populate the rural districts of the country you want money just as if you are to maintain your flect you want money. The Government's business is to recoucile the various claims male upon it. Sonething like three or four times a weck I am called in the House of Commons to a Committec meeting of rarious Members of Parliament, whose whole intention is to claim money from the Government. We sign petitions, we get ip agitations, we button-hole Irinisters, all with a view of getting them to spend money. It is well known to creryone who takes an interest in funance at all that during recent years a large portion of our floating deht has been in the hands of foreign bankers. At any moment they conld have ealled in that debt, and we should have had to meet it, and 1 helieve the result would have been almost as disastrous to this comtry as the loss of a great flect action in the Chamnel. That is Mr. Asguith's problem, and it is the difficulty of meeting it which $I$ think some of the speakers yesterday afternoon did not realise. Tlint is the reason $I \mathrm{am}$ speaking this afternoon, not because $I$ venture at all to argue on the merits or demerits of Lieutenant 13ellairs' paper. Personally I believe Iientenant Bellairs is doing a good work in Parliament by continually ngitating for the efficiency of the Nary; but rou must remember, in justice to Members of Parliament, that there is a great diversity of opinion even in naral circles on these matters. As a humble Member of I'arliament, I sat here this aftermoon and heard Sir William White's most volunble remirks, and they have a great influence on me, and before opposing the Government $I$ should have to consider all these things. I 
hure spoken to a great many Members of Parliament on this subject, and $\mathrm{my}$ orrn opinion is that the House of Commons, with remarkably few exceptions-probably a couple of dozen exceptions-will always rote the Gurernment such supplies as they require, if they are told there is the least danger of our naval supremacy being last. But we must, as ordinary humble laymen, follow the Board of Admiralty. If any of you, gentlemen, can prove conclusively to us who sit in the Commons that the Board of Admiralty is absolutely wrong, I believe wo would revolt almost to a man. I rould not renture to opeak for the Socialists, but I can speak for ordinary Members of Parliament. This is our difficulty, and this is the one thing I would venture to bring to your notice this aftemoon, that wo are not deliberately hostile to Army or Nary expenditure. I believe erery man almost in the House of Commons is prepared to make any sacrifice to ensure the safety of the Empire; but, if I may speak rery irankly, there is a certain danger that the constant cry of "Volf" may defeat its own object. You must remember that in the House of Cimmons we represent a large number of rotes. Un every platform I hare sat there was a great deal of talk about undue taxation and high rates, and I should, not have been a Member of Parliament to-day if I had not promised to do what I could to reduco tho taxes. I safeguarded myself by adding that I considered money must be spent upon the Nary te any ncedful degree. Beyond that I stand here pledged to econony, and so does practically every Member of Parliament. Even my opponent, who is not so happy as to bo a Member, if it is a happiness, which I rather doubt after ten consccutive months of it, was also pledged to cconomy. I humbly suggest to those here who take such a great interest in naral affairs, and guide public opinion, that they ought to confine themselves to pressing for what is absolutely essential for the welfare of the Navy. -l'hat Lieutenant Bellains says is perfectly true. If you can come to the House of Commons and say that a thing is absolutely essential, I believe snu will get it without any division at all; but as long as there is divided opinion we cannot hope to achieve that result. I thank you for listening to an ignorant layman, and I can only assure you what a plensure and great education it has been to me to como here, and $I$ hope it will not bo tho last timo I shall be allowed to be here.

Mr. Ronert Duscan, M.P.:-If not out of place, I should like to say a sentence or tro in regi $d$ to one matter of naval strength of which, as a body of experts helping to form and instruct public opinion, wo should take notice, and that is the expenditure on coaling-stations. Coal, or whatever fuel is used, being tho life of the Nary, nust be looked to, and if on that matter we can bring, individually or collectively, any influence on tho Government, it might bo exerted to see that a dus smount is spent on coaling stations, well selected, well equipped, and well guarded, all over the world.

Lieutenant Carcrox Belusins, in reply, said :-The reriard of any lecturer who comes to this Institution is the discussion which ho erokes, and I must confess that. I am rery well satisfied with the discusinge. Wo hare had representatives of almost every branch, representatives of the Army, tho $\mathrm{Navy}$, and the mast distinguished naral architect of our time in Sir William White. First, I should like to devote my remarks to something Admiral Hendereon said. He made some very valuable remarks about arertime. We must remember that if we gire in to the belief that wa are not to nork overtime, then all the ideas of rapid shipbuilding to a 
large extent fall to the ground, for though the Admiralty promised not to work orertine in connection with tho new "Dreadnoughts," they have begun already to work overtime in preparing tho slips, although the Labour Party has not yet found it out. Admiral Henderson said something abont trusting tho Board of Admiralty. If we look back on tho eccret history of the past, such as that rerealed by Admiral Sir Vesey Hamilton, when havo we found reason to trust tho Board of Adniralty, and, in many respects, the Sea Lords of the Admiralty? They brought forrard a Memorandum of November, 1005, laving down the ninimum programme, after pressure for economy had been brought to bear on them by tho last Government. Since then we havo lost the "Montagu," we have had the French and German programmes, and now we wonder why there is not an increased programme. Instead of that we have reductions. I think, to a largo extent, therefore, they have put themselves out of court. If we are to give a complete trust to the loard of Admiralty; that would apply to all the discussions. We must discuss these things if we are to have a proper state of things. Sir William White gave us some very valuable remarks about the absurdity of the secrecy in connection with the new ships, and Captain Caborne referred to the fancy quick building of the "Dreadnought." I do not believe the "Dreadnought's" guns are the guns that were bouglit for the "Dreadnought"; I believe they were the guns ordered for the "Lord Nelson" and tho 'Agamemnon.' I' know that six months before the ship was laid down material had been ordered, and I know an arerage of 1,200 men were daily morking overtime on board that ship. No men worked overtime on the other battle-ship building, the "Britannia," and over twice as many men wero daily employed on building the "Dreadnought. At times the numbers went well orer 1,500 working orertime. I now come to the rexcl question of unarmoured ends, with which Sir William White and Admiral Fremantle dealt. Sir William White referred to the battle of Tsushima, and referred to the complete belted ships. He took them as instances of belted ships sinking. They mere heavily loaded ships, carrying stores to Vladirostok. The effect of orerloading was precisely the same as unarmoured ends; there were nnarmoured portions of the ship in ecintact with the water-line, and that is just our contention of the danger. I hare giren a list of the umarmoured ends in Appendix $B$, and $I$ hope that will be studied. You will find that only 13 battle-ships of tho British Navy are completely belted from end to end, and that is a nost vital point in the view of naval officers because of modern gunnery. We know 'perfectly. well that the renson why the Germans built their battleslups with large secondary rimaments was because we had this enormous number of unarmoured end ships in the British Navy. They said: "We can bring our 6-inch guns to bear on the unarmoured portions of the water-lines of British ships." Sir Nathanicl Bowden-Smith and others referred to our being up to the tro-Power standard at present, but tho question of our strength at present was a question we were considering threo or four years ago, and has nothing whatever to do with what we haro $t_{\text {, }}$ crensider now. We introduce a shipbuilding progranme not according fo our strength at the present time, but according to what our strength will be four years hence in relation to the next two naval Powers, au 1 that of course is the most important point we have to consider. I assert - -and it is confirmed by erery single table in the Appendices-that wo shall not be up to the two-Power standard four years hence if the curtailed programme for 1907-8 is persisted in. Then there is the question of the rapidity with which we build. It shows the danger of a great authority 
liko Sir William White making statements in the Timcs. Sir Nathanicl Bowden-Smitl inmediately comes forward and eays we build much noro rapidly than other nations, and the same statement was made by nearls every speaker in the House. Sir William White nerer disputed my con tention in his spech, never attempted to dispute the fact that tho Gernans build just as rapidly as we do. He told us it was a question of finance, and no one doubts thint it is, and if you choose to rote more money cach year you can build quicker. I have analysed every singe buttle-ship built in recent years, and shown that the statement made in the Ilouse of Commons by the Prime Minister is not true, viz., that the Germans do not build as rapidly as we do. What Sir William White shored in the rimes was that we have greater resources, but that has nothing to do with the rapidity of building. Will Sir William White go as an umpire at a race meeting when a 100 varels race is being rum and arard the prize to the loser on the ground that the loser wou'd have won if it had been a half-mile race? Such an umpire would be hissed off the course. Really, in a case of such importance as this I do not think the matter ought to be looked upon in that way; it is simply throwing dust in the eyes of the public. By going into claborate calculations as to our resources and saying therefore we are building faster is throwing. In in the eyes of the public. Neither nation is trying to build up to $\mathrm{C}$; resources. lihe question of our ability to build 16 armoured ships a year and the Germans 8 docs not enter into the matter at all. Sir Nathanicl Bowden-Smith made comparisons of our strength with Germany alone. The whole idea of being absolutely certain of our ground is that we may liare to figlit two l'owers and even to provide for a neutral lower, and certainly we should not be able to put our best ships into the Channel and leave all our unarmoured end ships in the Mediterranean. The French are concentrating the whole of their effort in the Mediterranean, and that is put forward in the papers as an instance of the friendliness of the French for Fingland. But do not the pcople who use that argument sce that it is also an instance of the friendliness of France for Germnny. France is putting the whole of lier flect where there are important British interests, and taking away her flect from near the North Sen, where all the German interests are concentrated. Now, Sir Nathaniel BowdenSnith referred to scares. Well, nobody wants a scare. I do not suppose anybody who came to this mecting thonght we were trying to engincer a seare, or he would hare stopped away. We look on our efforts just now ni purely educatiomal. l3ut if you do not incrcase vour programmes in future year's we say you will get a scare right enough. "We wạnt to nroid a searc. Mr. Beck made a spcech with which I was delighted. I wish the attitude oi erery Member of Parliament to this question ras the same as his attitude. He wants to be convinced and get at the truth, and if he gets at the truth $I$ think he will be perfectly fearless in naintaining our naral supremacy. I wish they were all like him. IIo mentioned what is a most important statement: that we meant permanent social reforms, and that costs moncy, which will have to go out erery year. That proves my statement that the money we are saving now is looked upon as already allotted for permanent reforms-that is to say, it is entirely last to the Nary. That is the danger of arguments like Sir . illiam White's in farour of postponement of ships. Now that the Sea Jords have allowed the shipbuilding rotes to go down, and promise that they will go down mucli lower next year, we shall all hare to put our shoulders to the whecl before we shall be ahle to get those rotes up. again. sir Willian White nerer contended that you would not lare to build in the 
future; he.said we might safely postpone some of the building. Sir Charles Camplell yesterday referred to one of those.projects which I think lead to the dispersion of our expenditure; he wanted a canal through Scotland at a cost exceding ten millipn pounds. I want battle-ships and cruisers, which are vital; I do not think the canal is of vital necessity. It may be useful, but $I$ do. not think it is rital, and 1 strongly deprecate the demand being raised at the'present moment, when we hare a predominance of Scotch Ministers in the Cabinet. We have from the Prime Minister downwards, with Lord Rosebery attacking on the flanks, Scotsmen all! Captain Crutchley rather took me to tasls about teaching history in the schools. I entirely agree that the Nary League is doing a most admirable work as regards history in schools, but what is that amongst 4.1 millions of people? What I was referring to was that there is no efiort whaterer on the part of the Government of the country to teach history in the schools. The efforts of the Nary League, admirable as they are as an example to all others, are a mere drop in the ocean compared to what is needed in order to educate the rast army of voters who will rum us 10 years hence. Mr. Bcauchamp referred to the "Invincibles," and said what we all say-and Sir William White said the same thing-that we never know what to call them. What we object to is the confidence trick: connting ships at one and the same time as battle-ships and as cruisers. Wither they are battle-ships or they are cruisers. 'The samo thing occurred in the old days. They were too clever by half. They built 50-gun ships which they said were battle-ships and frigates, and they nerer were a sucecss. I think that example in history should bo remembered. We, are doing exactly the same confidence trick with the destroyers. We have these coastal destroyers half the tonnage and utterly inferior in armament to the destrojers the Germans are building, and thpugh not fit to operate on the enemy's coast, they are reckoned as destroyers!. The Germans are going right aheal of us with their pro'gramme of 12 destroyers a year. With reference to Mr. Beauchamp's important point about skeleton and nucleus crews, it emphasises our diffenlty in the House of Commons. We cannot get any information of any sort sut of the Almiralty, and therefore cannot hare discussion. The Ilouse is. asked blindly to trust the experts. I do not think that is right. We are quite entitled to know what the slscleton crews are, and what the nucleus crers are. You can call two men and a boy a skeleton crew. I'crhaps the Admiralty are going to do the right thing and have large crews, but I do not beliere they are. My own view about the two-Power standard is that one of the best means of attaining it would bo for the First Iord's statement every year.to include the names of the forcign battle-ships which were taken into consideration by the Board at the time the Estimates rere framed. Then, if an additional battle-ship is laid down by one of tho two principal foreign lowers, it ought to be an understood thing that we should lay down an additional battle-ship to mect her. Sir William White dealt with the programmes of the foreign l'owers, and referred to the fact that of the French battle-ships, only tro wonld be ready by 1910 and four by 1011. That was the very point I tcok into consideration in my paper. I said it was not neccssary, owing to the slomness of building in France, to take those battle-ships into consideration until 1008-9 programme, which would be completed under favourable circumstances in 1910-11. But I sliored that we should have a programme of three this year, seven the next, and nine or ten the year after, and I carried the ineeting with me wlien I said that that was a rery uncconomical way of proceding, that it was far better to have five 
armoured ships a year than ten battle-ships. in the future. There is only ono thing more that $I$ desire to refer to. Sir William White, to a certain extent, proved that in the naval view unarmoured ends were right when they. were first brought in. That may bo so, but invention went along, and we got the Harveyised armour, by which yon can defend twice the area with the same weight of armour, and I doubt whether unarmoured ends were right after that. At any rate, foreign Powers continued to build complete belted ships, and said they could sink our ships with their sccondary armaments, whereas we went on with the unarmoured ends. Sir William White undoubtedly, in the ships that he designed, brought the Nary to a very high pitch of efficiency, so that we carried through the Fashoda crisis with an expenditure of only 213,000 extra; but it is perfectly certain that those ships that stood us in ouch good stead at tho time of the Fashoda crisis, with the modern derelopments of gumery and such marrellous shooting as the "Drake" made-75 per cent. of hits at 4 miles' range-those-ships with unarmoured ends rould not possibly arail in battle to-day.

The Cummesay (Adniral Sir R. H. Harris, K.C.B., K.C.MI.G.) :-I think you will all join with me in agreeing that this has been a most raluable lecture, and that the Institution is to be congratulated on having the presenco of so many Members of Parliament. It certainly is a great thing for us and a great thing for the Navy that naval matters should le thoroughly well understeod by those people who represent the country in Parliament, and who have tho whole power of finance in their hands. It is money" which gives us a big Naiy, and unless the Members are prepared to rote, and the constituents approve of their rote, the money is not forthcoming. Modern wars must be short, sharp, and decisive. Thero is no nation in Europo capable of carrying out a war with a neighbour for more than eighteen months or two years; they would be by that timo financially broken. Much moro likely is it that in the next naval war ene nation or the other will be brought to its knees within the first weck or ten days. Therefore $I$ say, in reckoning ap our naval strength, that naral strength should haro a sufficiently large margin to replace thoso casualtics that might happen accidentally or through the better strategy of the enemy-casualties that may make a flect in the first week possibly inferior to its opponent. We have an instance of this in the RussoJapanese war. I inagine that when a war between ourselves and any Continental Power, say Denmark, for instance, took place (I say Denmark because I do not wish to name the Power I havo in mind), their destrojers, which are the equal of our own destroyers, would first attack our battleehips, and I think our force of destroyers is not up to the standard strength to that it should be kept at to prevent suclf an attack. Timo does not permit me to say much more, but I wish to mention the increased size of battle-ships. Is we increase the size of battle-ships wo have to build nearly two to the one $\& \subseteq$ other. Powers, and therefore tho expenso is very much greater. Ono "Dreadinought" is supposed to equal four older class vessels, but the risk to one of these ships oi being destroyed or disabled by a Whitehend torpedo or a submarine mine is just as great as the risk of the smaller ships, while in the erent of a "Dreadnought" being destrojed, it is equal to miping ont four battle-ships instead of one. All this has to be taken into consideration in measuring naval strength. Returning to what I said at the beginning of my remarks, I maintain that crery ship should be bept in an absoute state of fighting efficiency. That 


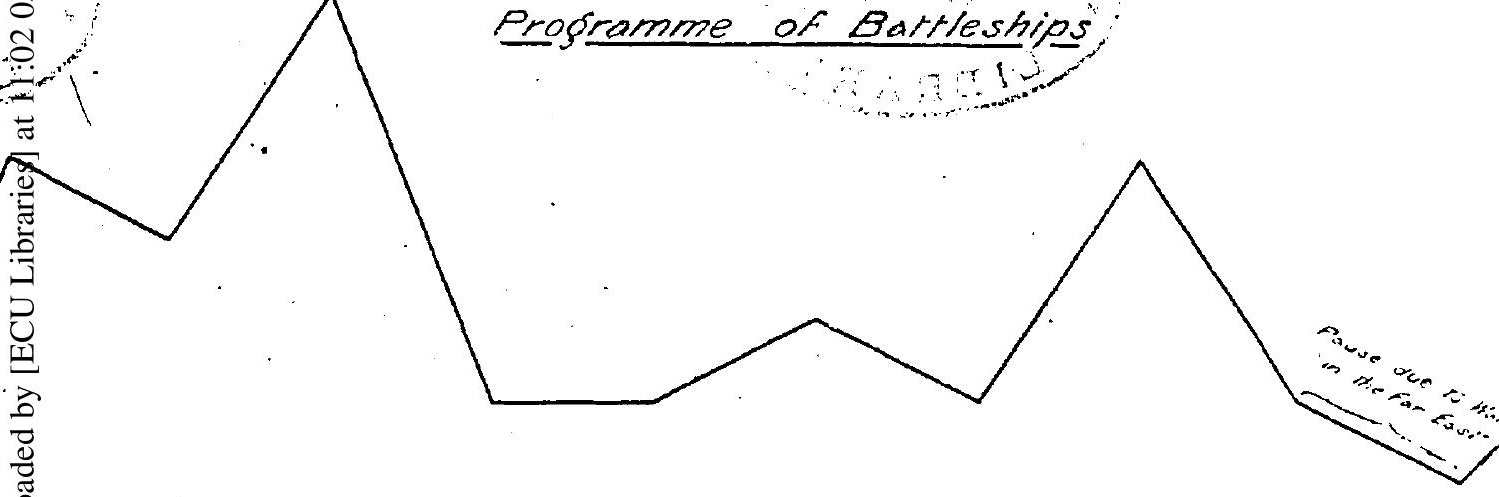

Geroina ergoramone since $1898 \equiv 2$ Battleships a yeac

\section{Programme of Armoured orher Cruisers.}

,

(

1

1

1

1
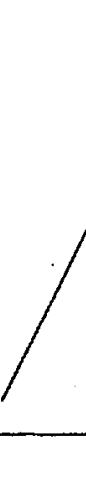

\section{F}

Programme of Destroyers 
is a greater safeguard than relative numerical naval strength; but can wo say that a ship with a nucleus or skeleton crew, with her complement newly completed and turned out to sea to fight a battle, is in a state of absolute sea-going fighting efficiency? She mas be 60 on paper, but I do not think she will be found so in practice. I thank the lecturer in our nemes for his very valuable paper, and congratulato him on the excellent discussion that has followed it-a discussion which $I$ think is alınost unique in this Institution. 